\title{
New U-Pb (SHRIMP) and first Hf isotope constraints on the Tonian (1000-920 Ma) Cariris Velhos event, Borborema Province, NE Brazil
}

\author{
Fabrício de Andrade Caxito ${ }^{*}$ iD, Lauro Cézar Montefalco de Lira Santos ${ }^{2}$ (D), \\ Alexandre Uhlein ${ }^{1}$ (D), Elton Luiz Dantas ${ }^{3}$ (D), Ana Ramalho Alkmim ${ }^{4}$, Cristiano Lana ${ }^{4}$ (D)
}

\begin{abstract}
Orthogneisses associated with metavolcanosedimentary successions related to the 1000 - $920 \mathrm{Ma}$ Cariris Velhos event occur mainly in a ca. $700 \mathrm{~km}$-long sigmoidal-shaped belt that crosscuts the Transversal Zone of the Borborema Province and extends to the fold belts located in its southern or external zone (part of the Riacho do Pontal and Sergipano orogens). Despite its importance, the tectonic setting and the role of those rocks in the geological evolution of the Borborema Province are contentious and not yet well understood. New zircon U-Pb SHRIMP data on an augen-gneiss sill of the Afeição Suite intruding mica-schists mapped as part of the Santa Filomena Complex yielded a Concordia Age of $974 \pm 11 \mathrm{Ma}$, indicating that at least part of the metasedimentary rocks in the internal zone of the Riacho do Pontal Orogen are Tonian or older and possibly related to the Cariris Velhos event. Hf-in-zircon isotope data are presented for the first time for Cariris Velhos-related ortho-derived rocks of the Afeição Suite. Analyzed samples yielded $\varepsilon \mathrm{Hf}(\mathrm{t})$ in a narrow range between -1.51 and +2.41 , with associated $\mathrm{T}_{\mathrm{DMHf}}$ of 1.6-1.4 Ga, similar to previously obtained $\mathrm{Nd}$ isotope data with $\varepsilon \mathrm{Nd}(\mathrm{t})=-1.0$ to +3.1 and $\mathrm{T}_{\mathrm{DMNd}}$ of $1.5-1.2 \mathrm{Ga}$. A possible scenario to explain both the geochemical features and the moderately juvenile to slightly evolved, near-chondritic $\mathrm{Hf}$ and $\mathrm{Nd}$ isotope signatures is a continental arc setting, where fractionated melts produced in the supra-subduction zone mantle wedge carrying a Tonian juvenile signature became contaminated with discrete amounts of Archean-Paleoproterozoic continental crust during ascent, producing Mesoproterozoic model ages which represent the mixture of those two end-members.
\end{abstract}

KEYWORDS: U-Pb SHRIMP geochronology; Hf isotope analysis; Cariris Velhos; Borborema Province.

\section{INTRODUCTION}

The Borborema Province of northeastern Brazil (Fig. 1) and its counterparts in northwestern Africa (the Tuareg Shield, the Benino-Nigerian Shield, and related provinces in Cameroon) are part of the broad orogenic network involved in the amalgamation of West Gondwana during the Ediacaran-Cambrian (ca. 630 - $500 \mathrm{Ma}$ ) Brasiliano/Pan-African Orogeny (Almeida et al. 1981, Brito Neves et al.2000). Although broad continuity of structural, stratigraphic and tectonic features was recognized for decades between the Borborema Province and provinces in NW Africa (Hurley et al. 1967, Caby 1989, Trompette 1994, 1997, Brito Neves et al. 2002, Oliveira et al. 2006, Arthaud et al. 2008, Dada 2008, Van Schmus et al. 2008, Araújo et al. 2014, 2016), there are still some major correlation problems between them. One of the major issues lies in the recognition

\footnotetext{
${ }^{1}$ Universidade Federal de Minas Gerais - Belo Horizonte (MG), Brazil. E-mails: caxito@ufmg.br, auhlein@gmail.com

${ }^{2}$ Universidade Federal de Pernambuco - Recife (PE), Brazil. E-mail: lauromontefalco@gmail.com

${ }^{3}$ Universidade de Brasília - Brasília (DF), Brazil. E-mail: elton@unb.br

${ }^{4}$ Universidade Federal de Ouro Preto - Ouro Preto (MG), Brazil. E-mail:ana_alkmim@yahoo.com.br, cristianodeclana@gmail.com ${ }^{*}$ Corresponding author.
}

(C) 2020 The authors. This is an open access article distributed under the terms of the Creative Commons license. and definition of ca. 1000 - 920 Ma plutonic and metavolcanosedimentary rocks within the central and southern Borborema Province, encompassing the Cariris Velhos event (Brito Neves et al. 1995, Kozuch 2003, Santos et al. 2010). Rocks in this age range have not yet been unequivocally recognized in NW Africa, and interpretations of its geodynamic setting and role in the Borborema Province are contentious, resulting in the proposition of both continental arc (Kozuch 2003, Medeiros 2004, Santos et al. 2010, Caxito et al. 2014b) and intracontinental rift (Neves 2003, Guimarães et al. 2012) models.

In this paper, we present new U-Pb SHRIMP data on zircon crystals from an augen-gneiss sill of the Afeição Suite that intrudes mica-schists mapped as part of the Santa Filomena Complex within the internal zone of the Riacho do Pontal Orogen, representing the Cariris Velhos event in the southern Borborema Province. We also present the first Hf isotope data for this and other occurrences of the Afeição Suite previously studied by Caxito et al. (2014b). The aim of the study is to contribute with new geochronological and isotopic data which will help to constrain the tectonic setting, petrological evolution and meaning of the Cariris Velhos event in the evolution of the Borborema Province.

\section{Geological context}

For descriptive purposes, the Borborema Province is generally subdivided into three broad tectonic zones (Northern, 
Transversal, and Southern subprovinces; Brito Neves et al. 2000, Van Schmus et al. 2011) separated by major (continental-scale) late-orogenic structural lineaments (the Patos and
Pernambuco shear zones; Fig. 1). The tectonic arrangement of the province results largely from the assembly of the major São Francisco-Congo, São Luís-West African and Amazonian

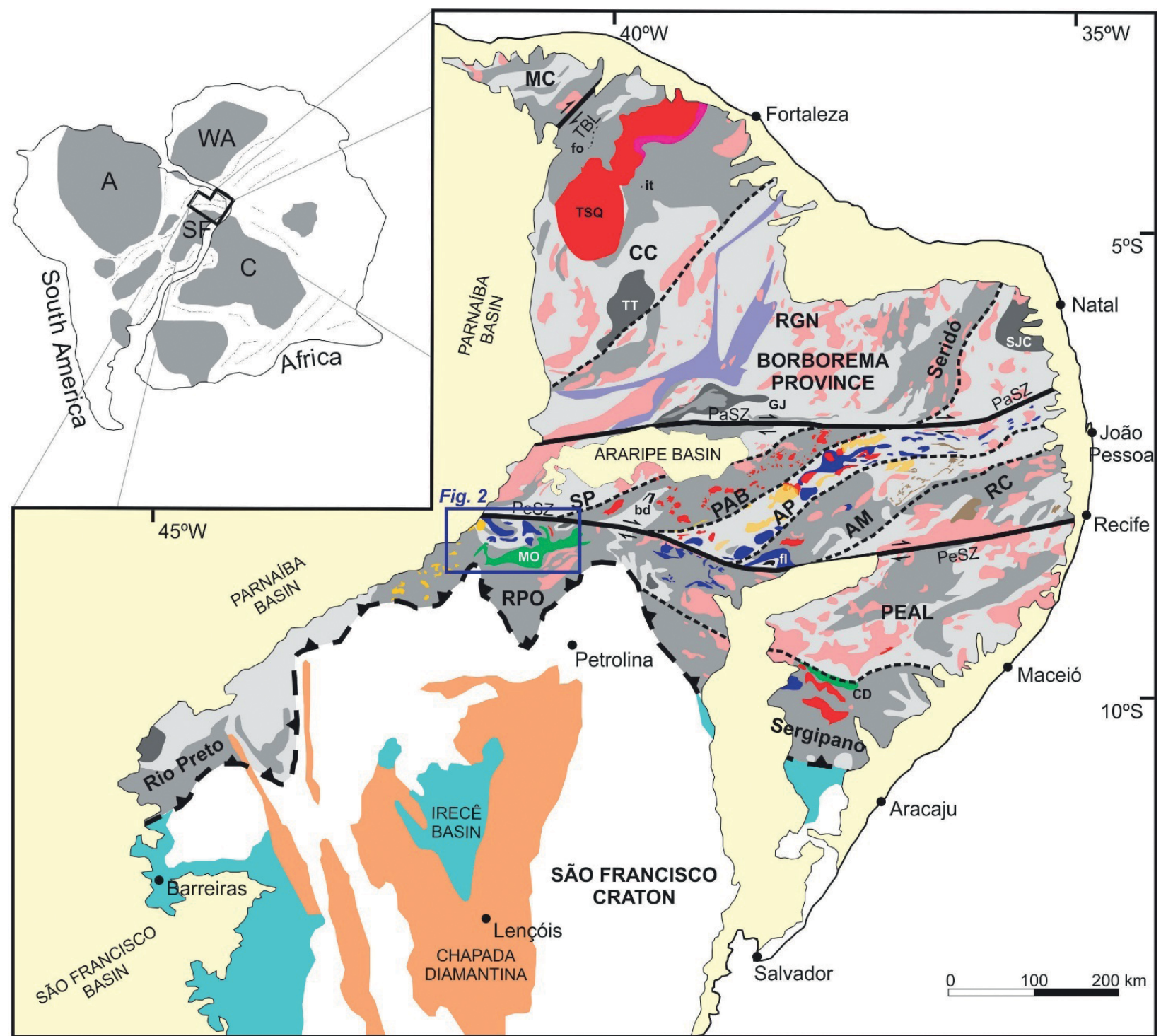

\section{Phanerozoic covers}

Late- to post-collisional High-K granitoids and syenites (syenitoid line - Stage III-V) - 590-530 Ma

Eclogite relicts (630-610 Ma) fo - Forquilha bd - Bodocó (?) it - Itataia $\mathrm{fl}$ - Floresta

Undifferentiated Brasiliano-aged granitoids (both syn-collisional and syn-transcurrent - Stage II/IV) - 625-550 Ma

Calc-alkaline, continental arc (?) granitoids (Stage I) 640-625 Ma

TSQ - Tamboril-Santa Quitéria Complex

Lagoa Caiçara Unit - juvenile orthogneisses (870-800 Ma)

Metavolcanosedimentary belts (mostly $<650 \mathrm{Ma}$ )

Ophiolite complexes (820-650 Ma)

$\mathrm{MO}$ - Monte Orebe

$\mathrm{CD}$ - Canindé

Cariris Velhos-aged orthogneisses (1000-960 Ma)
Paleo/Mesoproterozoic plutons (ca. 1.7-1.5 Ga)

Orós-Jaguaribeano Belt (ca. 1.8-1.7 Ga)

Borborema Province basement $(>=2.0 \mathrm{Ga})$

Major Archean inliers

TT - Tróia-Tauá (Pedra Branca) - 2.7-2.5 Ga

GJ - Granjeiro - 2.8-2.7 Ga

SJC - São José do Campestre - 3.5-2.7 Ga

Neoproterozoic cratonic covers

Mesoproterozoic cratonic covers

São Francisco Craton basement (>2.0 Ga)

São Francisco Craton / Borborema Province boundary thrust

Major strike-slip shear zones

.- Borborema Province subdomain's boundaries

PeSZ: Pernambuco Shear Zone; PaSZ: Patos Shear Zone; TBL: Transbrasiliano Lineament.

Figure 1. Simplified geological framework of the Borborema Province. Modified from Caxito et al. (2016), and references therein. Domains and sub-domains of the Borborema Province: PEAL: Pernambuco-Alagoas, RC: Rio Capibaribe, AM: Alto Moxotó, AP: Alto Pajeú, PAB: Piancó-Alto Brígida, SJC: São José do Caiano, RGN: Rio Grande do Norte, CC: Ceará Central. 
paleoplates, and smaller, intervening continental blocks such as the concealed Parnaíba block during the Neoproterozoic. As part of the Southern subprovince, the Riacho do Pontal Orogen (Brito Neves 1975, Caxito et al. 2016, 2017) borders the northern São Francisco craton margin in the southernmost Borborema Province.

Most occurrences of Cariris Velhos' aged rocks have been documented in a narrow and elongated sigmoidal belt in the central portion of the Borborema Province (roughly $100 \mathrm{~km}$ wide $\times 700 \mathrm{~km}$-long), comprising the Alto Pajeú and Riacho Gravatá domains of the Transversal Zone (Fig. 1; Santos et al. 1997, Kozuch 2003, Brito Neves et al. 2005, Van Schmus et al. 2008, 2011, Santos et al. 2010), but other important occurences have also been documented within the Southern subprovince, in the Poço Redondo-Marancó domain of the Sergipano Orogen (Carvalho 2005, Oliveira et al. 2010), in the Pernambuco-Alagoas domain (Silva Filho et al. 2002, 2014, Cruz et al. 2014), and in the northern portion of the Riacho do Pontal Orogen (Jardim de Sá et al. 1988, 1992, Van Schmus et al. 1995, Caxito et al. 2014b) where it comprises the Afeição augen-gneiss Suite.

In this work, samples of the Afeição Suite were studied as representatives of the Cariris Velhos event. Thus, a brief review of the geology of the Riacho do Pontal Orogen is here presented. For detailed descriptions, the reader is referred to Caxito (2013) and Caxito et al. $(2016,2017)$. According to the geophysical, sedimentary, igneous, metamorphic and structural characteristics, the Riacho do Pontal Orogen can be divided into three tectonostratigraphic zones or domains (Fig. 2): external, central, and internal (Oliveira 1998, Caxito 2013, Caxito et al. 2016).

The southernmost external zone is characterized by a south-verging nappe system, composed of supracrustal rocks that override the São Francisco craton basement in the Sobradinho dam area. They are composed mainly of metasedimentary clastic rocks of the Barra Bonita and Mandacaru formations, comprising, respectively, a platformal succession composed mainly of quartzite, garnet-mica schist, and marble intercalations, and a syn-orogenic basin composed of metagreywacke and garnet-mica schist, locally containing staurolite and kyanite, and with minor metavolcanoclastic intercalations (Caxito et al. 2016). The syn-orogenic metavolcanosedimentary rocks of the Mandacaru Formation contain ca. $650 \mathrm{Ma}$ detrital zircon grains (Brito Neves et al. 2015, Caxito et al. 2016) which attest for provenance from the Borborema Province (hinterland), while those are absent from the passive margin sedimentary rocks of the Barra Bonita Formation, characterized by provenance from the cratonic sources to the south (Caxito et al. 2016). The distinct sources and tectonic settings preclude joining the two formations in a single group, as previously proposed (“Casa Nova Group”, see Caxito et al. 2016).

The central zone is characterized by complex deformation involving both south-verging thrusts and E-W strike-slip shear zone systems, and is composed of the metavolcanosedimentary Monte Orebe Complex. This unit bears important metamafic rocks (actinolite-plagioclase greenschists) with MORB-like lithogeochemistry and juvenile $\varepsilon \mathrm{Nd}(\mathrm{t})$ signatures of +4.4 (Caxito et al.2014c) interleaved with deep-sea metasedimentary rocks including exhalites and local metaultramafic lenses. This unit is interpreted as composed of remnants of a Neoproterozoic ophiolite complex of ca. $820 \mathrm{Ma}$ (Sm-Nd whole-rock isochron), marking the development of new oceanic crust separating the Borborema Province from the São Francisco paleocontinent to the south. The geophysical signature of the central zone is marked by the inflection of a paired positive-negative Bougher anomaly which is typical of Precambrian suture zones (Oliveira 2008, Oliveira and Medeiros 2018) representing the site where ancient plates agglutinated. In this case, the lower plate (São Francisco paleocontinent) is represented by lower Bouguer values to the south while the upper one (western edge of the Pernambuco-Alagoas domain) is represented by higher Bouguer values to the north (Oliveira 2008, Caxito et al. 2014c, 2016, Oliveira and Medeiros 2018).

The internal zone, to the north, is characterized by abundant augen-gneiss intrusions (Afeição Suite), highly reworked Archean/Paleoproterozoic migmatitic basement slices, and predominantly metasedimentary units with important mafic volcanic and plutonic contributions (Paulistana and Santa Filomena complexes). It is bounded, to the north, by the E-W trending dextral strike-slip western branch of the Pernambuco shear zone.

The Santa Filomena Complex is composed of mica schist with abundant garnet, staurolite and sillimanite, quartzite, marble lenses, and minor metamafic intercalations. Detrital zircon contents suggest that at least part of the Santa Filomena Complex is younger than ca. $650 \mathrm{Ma}$, although samples collected in different sites yield distinct provenance patterns without the specific Cryogenian zircon grains and bearing only older, basement-derived grains (Brito Neves et al. 2015, Santos et al.2017). Peak metamorphic conditions are estimated at ca. $640^{\circ} \mathrm{C}$ and $12 \mathrm{kbar}$ (Santos et al. 2018).

The Paulistana and the Santa Filomena Complexes differ from one another by the absence of marble and by the abundance of mafic (metagabbros, amphibolites, and actinolite-schists) and ultramafic (talc-schist and pyroxenite) rock intercalations in the former. Zircon crystals extracted from a metagabbro yielded a Concordia age of $882.8 \pm 4 \mathrm{Ma}$ (Caxito et al. 2016), and detrital zircon contents suggest deposition after ca. $900 \mathrm{Ma}$ (Brito Neves et al. 2015, Santos et al. 2017). Based on the geochemical signatures of metabasalts and metagabbros, Caxito et al. (2016) interpreted the Paulistana Complex as part of a continental rift setting.

The western portion of the internal zone is dominated by a metavolcanosedimentary sequence, the Morro Branco Complex, composed mainly of metarhythmite with intercalations of metabasalt, metarhyolite, and mafic to intermediate metatuff. This sequence is intruded by the Brejo Seco Complex, a mafic-ultramafic intrusion that bears Ni-Cu-PGE deposits crystallized at ca. $900 \mathrm{Ma}$ (Sm-Nd whole-rock isochron; Salgado et al. 2016). The Brejo Seco Complex is interpreted as intruded in a continental extension setting related to the emplacement of a mantle plume (Salgado et al. 2016).

The whole supracrustal package of the Riacho do Pontal Orogen is intruded by multiple generations of pre-, syn- and 
post-collisional granitic and syenitic plutons. The calc-alkaline Betânia Granite in the internal zone is interpreted as part of a continental arc. Zircon crystals from this granite yielded a 628.7 2.3 Ma Concordia Age (LA-ICPMS, Perpétuo 2017). The syn-collisional two-mica Rajada orthogneisses are dated at ca. $610 \mathrm{Ma}$ (Brito Neves et al. 2015, Caxito et al. 2016). The post-collisional Serra da Aldeia syenites are dated at ca. 586 - $576 \mathrm{Ma}$ (Caxito et al. 2016, Perpétuo 2017).

The Afeição augen-gneiss Suite crops out in the internal zone of the Riacho do Pontal Orogen, about $100 \mathrm{~km}$ southwestward of the closest Cariris Velhos occurrence within the Transversal Zone. Those rocks became a major target for the study of the Cariris Velhos Belt after a Rb-Sr whole-rock isochron of $968 \pm 35$ Ma was presented (Jardim de Sá et al. 1988) as the first Tonian age obtained in the Southern subprovince of the Borborema Province. This age was later confirmed by a U-Pb TIMS age of $966 \pm 10 \mathrm{Ma}$ on zircon crystals from an augen-gneiss of the Afeição Farm, type-locality for the Afeição Suite (Van Schmus et al. 1995), by LA-ICPMS dating of augen-gneisses near São Francisco de Assis, Piauí, at $985 \pm$ $18 \mathrm{Ma}$ (Freitas and Sachs 2012), and by two LA-ICPMS zircon U-Pb Concordia ages of a granitic sill at $1001.8 \pm 4.5 \mathrm{Ma}$ and of a different augen-gneiss body at $966 \pm 4.6 \mathrm{Ma}$ (Caxito et al. 2014b).

A detailed study comprising the petrography, geochemistry, and isotope geology of the Afeição Suite was presented by Caxito
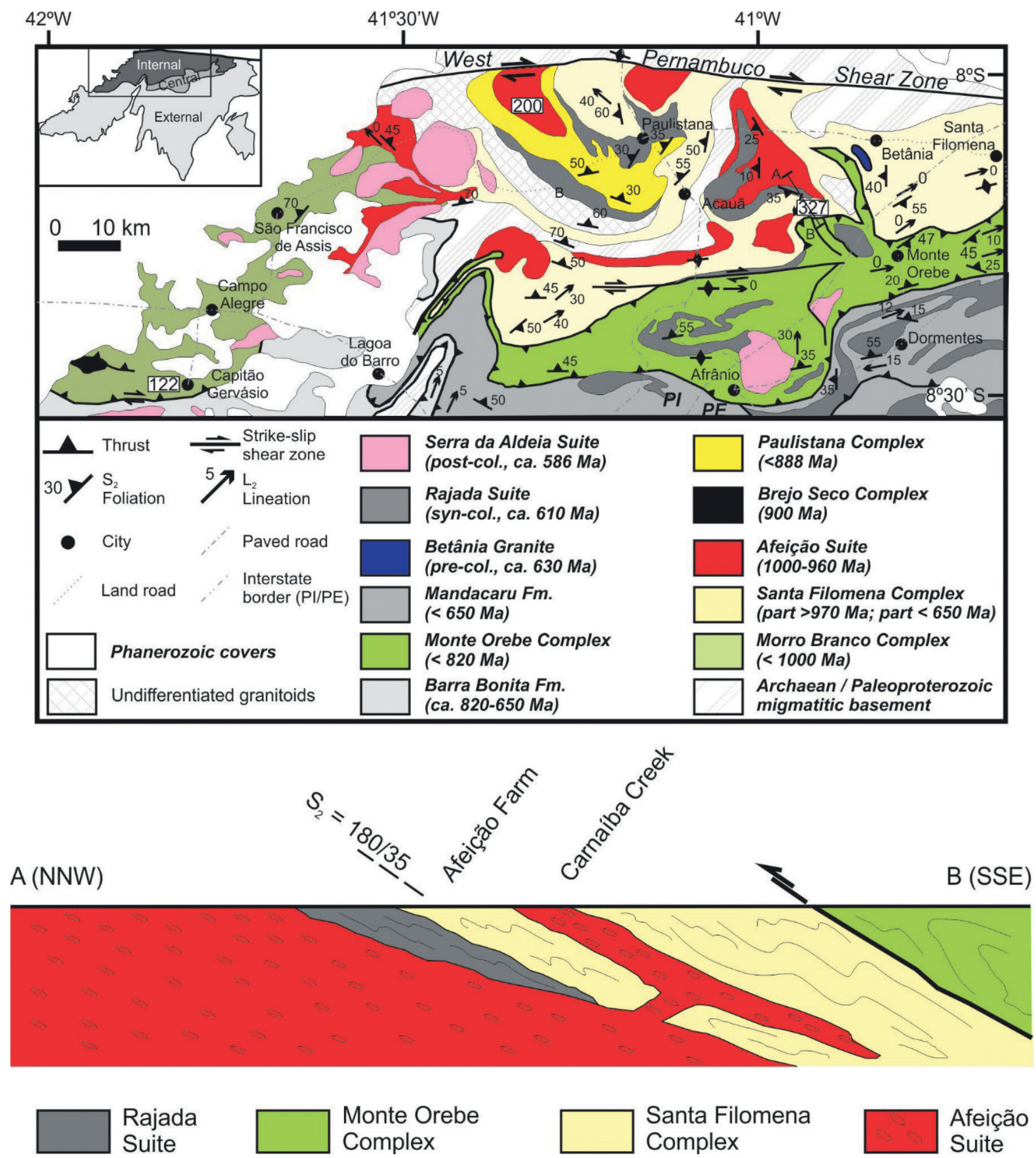

Afeição

Suite

Figure 2. Simplified map of the internal zone of the Riacho do Pontal Orogen (see location in Fig. 1) and transect of the Carnaíba Creek area. Location of samples used in this study are marked by a white stripe; the numbers are for sample identification (sample code $=\mathrm{FRP}+$ number shown). Modified from Caxito et al. (2014c). 
et al. (2014b) and a brief description of its results is presented herein. The Afeição Suite is composed mostly of calc-alkaline, high-K, slightly metaluminous to slightly peraluminous (mol $\mathrm{Al}_{2} \mathrm{O}_{3} /\left(\mathrm{CaO}+\mathrm{K}_{2} \mathrm{O}+\mathrm{Na}_{2} \mathrm{O}\right)=0.94$ to 1.16 , mean 1.04 - please note that samples are plotted incorrectly in Fig. 5B of Caxito et al. (2014b) due to a graphics error), high-silica ferroan and magnesian granites. Chondrite-normalized REE patterns are moderately to highly fractionated, with a pronounced negative Eu anomaly. Incompatible element spidergrams show a negative $\mathrm{Nb}$ - $\mathrm{Ta}$ anomaly, normally resulting from $\mathrm{Nb}$-Ta-bearing phases such as magnetite, titanite, rutile, biotite, among others, left on the cumulate or in the restite, akin to convergence setting (Cordilleran-type) granites. Values of $\varepsilon \mathrm{Nd}(\mathrm{t})$ between -1.0 and +3.1 and $\mathrm{T}_{\mathrm{DM}}$ of $1.2-1.5 \mathrm{Ga}$ suggest variable mixing of Tonian juvenile sources with older crustal sources involving Archean/Paleoproterozoic basement. According to previous models proposed for the Cariris Velhos event (e.g., Kozuch 2003, Medeiros 2004, Santos et al. 2010), Caxito et al. (2014b) interpreted the Afeição Suite as the southwestern edge of a continental margin magmatic arc accreted to this portion of West Gondwana during the early Tonian. Late-Brasiliano dextral displacement through the western branch of the Pernambuco shear zone separated these Cariris Velhos occurrences from their equivalents within the Transversal Zone of the Borborema Province (e.g., the Recanto-type augen-gneiss of the Alto Pajeú Domain; Santos et al. 2010).

Caxito et al. (2016) interpreted the development of a complete Wilson Cycle during the Neoproterozoic in the Riacho do Pontal Orogen area. A five-stage model is proposed:

1. rift phase, with the development of a triple junction system at ca. 900 - 820 Ma ago, leading to intense mafic-ultramafic magmatism of the Brejo Seco Ni-Cu-PGE mineralized layered intrusion probably related to a plume head. This was followed by development of the Paulistana Complex metavolcanosedimentary sequence, with metagabbros and metabasalts dated at ca. $882 \mathrm{Ma}$ and younger detrital zircons at ca. $900 \mathrm{Ma}$;

2. drift phase: evolution of the rift system to a broad passive margin in the northern São Francisco paleocontinent edge, represented by the Barra Bonita Formation platformal sediments. This drift phase caused by continued continental stretching culminated in the development of new oceanic crust, represented by the Monte Orebe ophiolitic complex around $820 \mathrm{Ma}$ ago;

3. convergence phase: started at ca. $630-620 \mathrm{Ma}$, with emplacement of the calc-alkaline Betânia granite, probably related to a continental magmatic arc setting, culminating in inversion of the basins, obduction of oceanic crust slices, and sedimentation of the Mandacaru Formation syn-orogenic greywackes, with younger detrital zircon populations at ca. $650 \mathrm{Ma}$;

4. collisional phase: continental collision between the São Franciscopaleocontinent (lower plate) and the PernambucoAlagoas block (upperplate) around 620-590 Ma, with stacking of the external nappes upon the lower plate, crustal thickening, deformation, metamorphism, melt generation and intrusion of the syn-collisional Rajada Suite two-mica granites;
5. lateral escape phase - this stage occurred around 590 $530 \mathrm{Ma}$, generating the western branch of the E-W trending Pernambuco Shear Zone, which truncates the northern part of the orogen. This phase was accompanied by extensive alkaline magmatism of the Serra da Aldeia suite, at 586 - $576 \mathrm{Ma}$.

In this scenario, the São Francisco paleocontinent would represent the lower, subducted plate, while the western edge of the Pernambuco-Alagoas domain would represent the upper plate. The Afeição augen-gneiss intrusions would be part of the latter, as augen-gneisses of this age range are absent from the São Francisco Craton region. Thus, the lower and upper plates present distinct geological features, which are reflected in distinct geophysical signatures (Oliveira 2008, Oliveira and Medeiros 2018).

\section{MATERIALS AND METHODS}

U-Pb Sensitive High-Resolution Ion Microprobe (SHRIMP) analysis (Tab. 1) was performed in zircon crystals separated through standard crushing, sieving, magnetic, and gravimetric methods from homogeneous portions (i.e., bearing no veins, fractures or alteration fronts) of ca. $15 \mathrm{kgs}$ of sample FRP327G in the Laboratório de Separação Mineral de Alta Pureza (SEPURA) at CPMTC, IGC-UFMG. Zircon crystals from samples FRP122 and FRP200 have previously been analyzed for U-Pb isotopes through Laser Ablation - Induction Coupled Plasma Mass Spectrometry (LA-ICPMS) at Laboratório de Estudos Geodinâmicos e Ambientais, UnB, and results and preparation methods were previously reported by Caxito et al. (2014b). Zircon crystals from all of those samples were further analysed for Hf isotopes at Laboratório de Geoquímica Isotópica, UFOP. Sample coordinates are presented along with Hf isotope results in Table 2.

After mounting in epoxy and polishing, zircon crystals were imaged through standard Scanning Electron Microscopy (SEM) techniques such as Secondary Electrons (SE), BackScattered Electrons (BSE) and Cathodoluminescence (CL) in a TESCAN Vega SEM in the Centre for Microscopy and Microanalysis (CMCA) at the University of Western Australia, Perth. The images were used for spot positioning based on the study of crystals features such as cores and rims, zones of damage by $\mathrm{U}$ radioactive decay, zones of inclusions, etc. The FRP327G sample mount was analysed for U-Pb isotopes and concentrations at the SHRIMP II Laboratory of the John de Laeter Centre, Curtin University, Perth, Australia. The mount was cleaned following internal standards of the centre and coated with gold for SHRIMP analyses, with a microprobe spot size of $20 \mu \mathrm{m}$. Six scans were performed for each spot, with nine peaks analysed at masses ${ }^{196} \mathrm{Zr}_{2} \mathrm{O},{ }^{204} \mathrm{~Pb}$, background, ${ }^{206} \mathrm{~Pb}$, ${ }^{207} \mathrm{~Pb},{ }^{208} \mathrm{~Pb},{ }^{238} \mathrm{U},{ }^{248} \mathrm{ThO}$, and ${ }^{254} \mathrm{UO}$. The NBS611 glass standard was used to identify the peak position of mass ${ }^{204} \mathrm{~Pb}$, whereas the calibration of the $\mathrm{U}$ contents and $\mathrm{Pb} / \mathrm{U}$ ratios were conducted using zircon standard Temora II (417 Ma; Black et al. 2004), which analysis was bracketed after each three or four unknows, yielding a Concordia Age of $416.4 \pm 3.3 \mathrm{Ma}(2 \sigma$; 
MSWD $=1.5 ; \mathrm{n}=25)$. The ${ }^{207} \mathrm{~Pb} /{ }^{206} \mathrm{~Pb}$ zircon standard used to monitor both instrument-induced mass fractionation and accuracy was OGC (3467 $\pm 3 \mathrm{Ma}$; Stern et al. 2009) yielding a Concordia Age of $3462.1 \pm 6.8 \mathrm{Ma}(2 \sigma ; \mathrm{MSWD}=0.73 ; \mathrm{n}=7)$ and $\mathrm{a}^{207} \mathrm{~Pb} /{ }^{206} \mathrm{~Pb}$ mean age of $3464.3 \pm 6.6 \mathrm{Ma}$. SHRIMP data were reduced using SQUID 2.5 software (Ludwig 2009) and plots were prepared using ISOPLOT 4.15 (Ludwig 2008).

Hf-isotope analyses (Tab. 2) were carried out in a ThermoFinnigan Neptune multicollector ICPMS coupled to a PhotonMachine laser system that delivers a beam of $193 \mathrm{~nm}$ UV light from a frequency-quintupled Nd:YAG laser hosted in Laboratório de Geoquímica Isotópica, Universidade Federal de Ouro Preto. The analyses were performed with a beam diameter of $50 \mu \mathrm{m}$, a repetition rate between 4 and $6 \mathrm{~Hz}$ and $50 \%$ of laser output. Depending on the conditions and Hf contents, the Hf signals were between 1 to $6 \times 10^{-11} \mathrm{~A}$ and ablation time lasted $60 \mathrm{~s}$. Ar carrier gas transported from the ablated sample from the laser ablation cell via mixing chamber to the ICPMS torch. To correct for the isobaric interferences of ${ }^{176} \mathrm{Lu}$ and ${ }^{176} \mathrm{Yb}$ on ${ }^{176} \mathrm{Hf}$, masses 172,173 , and $175-180$ were measured

Table 1. SHRIMP U-Pb data for sample FRP327G.

\begin{tabular}{|c|c|c|c|c|c|c|c|c|c|c|c|c|c|c|c|}
\hline Spot Name & $\underset{(\mathbf{p p m})}{\mathbf{U}}$ & $\mathbf{T h} / \mathbf{U}$ & $f_{206}(\%)$ & $\begin{array}{l}{ }^{207} \mathbf{P b} \\
{ }^{2235} \mathbf{U}\end{array}$ & $\pm \mathbf{1 \sigma}(\%)$ & $\begin{array}{l}{ }^{206} \mathbf{P b} \\
/{ }^{238} \mathrm{U}\end{array}$ & $\pm 1 \sigma(\%)$ & $\rho$ & $\begin{array}{l}{ }^{207} \mathbf{P b} \\
/{ }^{206} \mathbf{P b}\end{array}$ & $\pm 1 \sigma(\%)$ & $\begin{array}{c}{ }^{206} \mathrm{~Pb} /{ }^{238} \mathrm{U} \\
\text { Age }(\mathrm{Ma})\end{array}$ & $\pm 1 \sigma$ & $\begin{array}{c}{ }^{207} \mathrm{~Pb} /{ }^{206} \mathrm{~Pb} \\
\mathrm{Age}(\mathrm{Ma})\end{array}$ & $\pm \mathbf{1} \sigma$ & $\begin{array}{c}\text { Disc. } \\
(\%)\end{array}$ \\
\hline FRP327G-1.1 & 163 & 0.30 & 0.040 & 1.6336 & 2.55 & 0.162994 & 2.25 & 0.88 & 0.072688 & 1.21 & 973 & 20 & 1005 & 25 & 3.42 \\
\hline FRP327G-2.1 & 192 & 0.50 & 0.758 & 1.4189 & 2.93 & 0.141710 & 2.11 & 0.72 & 0.072619 & 2.04 & 854 & 17 & 1003 & 41 & 15.85 \\
\hline FRP327G-4.1 & 377 & 0.27 & 0.120 & 1.5940 & 2.03 & 0.160707 & 1.81 & 0.89 & 0.071936 & 0.91 & 961 & 16 & 984 & 19 & 2.56 \\
\hline FRP327G-5.1 & 614 & 0.08 & 0.357 & 1.4605 & 1.99 & 0.147117 & 1.67 & 0.84 & 0.072002 & 1.09 & 885 & 14 & 986 & 22 & 10.98 \\
\hline FRP327G-6.1 & 400 & 0.44 & 0.000 & 1.5740 & 1.93 & 0.159503 & 1.79 & 0.93 & 0.071569 & 0.70 & 954 & 16 & 974 & 14 & 2.18 \\
\hline FRP327G-7.1 & 142 & 0.35 & 0.265 & 1.5870 & 3.10 & 0.169753 & 2.39 & 0.77 & 0.067804 & 1.98 & 1011 & 22 & 863 & 41 & -18.57 \\
\hline FRP327G-8.1 & 2,011 & 0.11 & 0.694 & 1.5576 & 1.55 & 0.158283 & 1.35 & 0.87 & 0.071372 & 0.77 & 947 & 12 & 968 & 16 & 2.32 \\
\hline FRP327G-9.1 & 82 & 0.29 & 0.548 & 1.4380 & 4.20 & 0.156374 & 2.85 & 0.68 & 0.066695 & 3.09 & 937 & 25 & 828 & 64 & -14.05 \\
\hline FRP327G-9.2 & 22 & 0.05 & 1.821 & 0.9294 & 14.7 & 0.115319 & 5.10 & 0.35 & 0.058453 & 13.8 & 704 & 34 & 547 & 301 & -30.28 \\
\hline FRP327G-10.1 & 143 & 0.22 & 0.084 & 1.6405 & 2.67 & 0.167663 & 2.31 & 0.86 & 0.070963 & 1.35 & 999 & 21 & 956 & 28 & -4.84 \\
\hline FRP327G-11.1 & 597 & 0.51 & 0.207 & 1.5446 & 1.93 & 0.157111 & 1.70 & 0.88 & 0.071302 & 0.90 & 941 & 15 & 966 & 18 & 2.82 \\
\hline FRP327G-12.1 & 319 & 0.84 & 0.154 & 1.6025 & 2.18 & 0.162188 & 1.89 & 0.87 & 0.071662 & 1.09 & 969 & 17 & 976 & 22 & 0.82 \\
\hline FRP327G-13.1 & 192 & 0.64 & 0.214 & 1.4893 & 2.92 & 0.148600 & 2.17 & 0.74 & 0.072689 & 1.95 & 893 & 18 & 1005 & 40 & 11.95 \\
\hline FRP327G-14.1 & 45 & 0.33 & 0.604 & 1.1513 & 7.04 & 0.113985 & 3.85 & 0.55 & 0.073257 & 5.89 & 696 & 25 & 1021 & 119 & 33.59 \\
\hline FRP327G-14.2 & 242 & 0.64 & 0.555 & 1.4714 & 2.73 & 0.152853 & 2.03 & 0.74 & 0.069815 & 1.83 & 917 & 17 & 923 & 38 & 0.70 \\
\hline FRP327G-15.1 & 22 & 0.91 & 15.065 & 0.2274 & 79.1 & 0.045820 & 5.91 & 0.07 & 0.035989 & 78.9 & 289 & 17 & -632 & 2159 & 149.08 \\
\hline FRP327G-16.1 & 127 & 0.31 & 0.000 & 1.6354 & 2.80 & 0.165294 & 2.49 & 0.89 & 0.071757 & 1.29 & 986 & 23 & 979 & 26 & -0.78 \\
\hline FRP327G-17.1 & 76 & 0.32 & 0.000 & 1.3818 & 3.14 & 0.148652 & 1.90 & 0.60 & 0.067417 & 2.50 & 893 & 16 & 851 & 52 & -5.38 \\
\hline
\end{tabular}

Table 2. Hf isotope data for the analyzed samples.

\begin{tabular}{|c|c|c|c|c|c|c|c|c|c|}
\hline Spot Name & $\begin{array}{c}{ }^{176} \mathbf{L u} /{ }^{177} \mathbf{H f} \\
\text { (present) }\end{array}$ & $\pm 2 \sigma$ & $\begin{array}{c}{ }^{176} \mathbf{H f} /{ }^{177} \mathbf{H f} \\
\text { (present) }\end{array}$ & $\pm 2 \sigma$ & $\mathbf{t}(\mathbf{M a})$ & ${ }^{176} \mathbf{H f} /{ }^{177} \mathbf{H f}(\mathbf{t})$ & $\mathbf{e H f}(\mathbf{t})$ & $\pm 2 \sigma$ & $\mathbf{T}_{\mathrm{DM}}$ \\
\hline \multicolumn{10}{|c|}{ Sample FRP327-G (Lat 8¹3'53” / Long 4053'01”) } \\
\hline FRP327G-1.1 & 0.00183 & 0.000046 & 0.282163 & 0.00011 & $973 \pm 20$ & 0.282129 & -1.40 & 0.06 & 1.6 \\
\hline FRP327G-4.1 & 0.00051 & 0.000016 & 0.282179 & 0.00003 & $961 \pm 16$ & 0.282170 & -0.25 & 0.01 & 1.5 \\
\hline FRP327G-16.1 & 0.00109 & 0.000035 & 0.282218 & 0.00007 & $954 \pm 16$ & 0.282198 & 0.61 & 0.03 & 1.4 \\
\hline FRP327G-6.1 & 0.00114 & 0.000033 & 0.282164 & 0.00007 & $969 \pm 17$ & 0.282143 & -1.01 & 0.05 & 1.5 \\
\hline FRP327G-12.1 & 0.00104 & 0.000026 & 0.282170 & 0.00006 & $986 \pm 23$ & 0.282151 & -0.36 & 0.02 & 1.5 \\
\hline \multicolumn{10}{|c|}{ Sample FRP122 (Lat 8²9’25” / Long 4150’47”) } \\
\hline FRP122-z11 & 0.00112 & 0.000017 & 0.282240 & 0.00007 & $1000 \pm 6$ & 0.282219 & 2.38 & 0.05 & 1.4 \\
\hline FRP122-z24 & 0.00173 & 0.000036 & 0.282247 & 0.00011 & $999 \pm 6$ & 0.282214 & 2.20 & 0.06 & 1.4 \\
\hline FRP122-z3 & 0.00129 & 0.000016 & 0.282238 & 0.00010 & $1010 \pm 7$ & 0.282213 & 2.41 & 0.05 & 1.4 \\
\hline \multicolumn{10}{|c|}{ Sample FRP200 (Lat 8’3'56” / Long 41¹8’41”) } \\
\hline FRP200-z27 & 0.00063 & 0.000020 & 0.282169 & 0.00004 & $971 \pm 5$ & 0.282158 & -0.46 & 0.02 & 1.5 \\
\hline FRP200-z23 & 0.00038 & 0.000013 & 0.282180 & 0.00002 & $959 \pm 5$ & 0.282173 & -0.17 & 0.01 & 1.5 \\
\hline FRP200-z16 & 0.00036 & 0.000015 & 0.282173 & 0.00004 & $956 \pm 6$ & 0.282166 & -0.47 & 0.02 & 1.5 \\
\hline FRP200-z6 & 0.00057 & 0.000015 & 0.282148 & 0.00005 & $971 \pm 6$ & 0.282138 & -1.16 & 0.04 & 1.5 \\
\hline FRP200-z9 & 0.00048 & 0.000017 & 0.282141 & 0.00004 & $964 \pm 6$ & 0.282132 & -1.51 & 0.06 & 1.5 \\
\hline FRP200-z11 & 0.00129 & 0.00002 & 0.282164 & 0.0001 & $983 \pm 7$ & 0.282141 & -0.80 & 0.02 & 1.5 \\
\hline
\end{tabular}


in static- collection mode and simultaneously monitored. The ${ }^{177} \mathrm{Hf}$ signal intensity was ca. 10 V. LA-ICP-MC data were reduced using In-house Excel Spreadsheets.

The accuracy and external reproducibility of the $\mathrm{Lu}-\mathrm{Hf}$ results were monitored through the analysis of zircon standards Temora $\left({ }^{176} \mathrm{Hf} /{ }^{177} \mathrm{Hf}=0.282680 \pm 0.000031\right.$; Black et al .2003 , Wu et al. 2006), Blue Berry $\left({ }^{176} \mathrm{Hf} /{ }^{177} \mathrm{Hf}=0.281674 \pm 0.000018\right.$; Santos, M.M. et al. 2017), Mud Tank $\left({ }^{176} \mathrm{Hf} /{ }^{177} \mathrm{Hf}=0.282504\right.$ \pm 0.000044; Black and Gulson 1978, Woodhead and Hergt 2005), GJ-1 $\left({ }^{176} \mathrm{Hf} /{ }^{177} \mathrm{Hf}=0.282000 \pm 0.000005\right.$; Jackson et al. 2004) and Plešovice $\left({ }^{176} \mathrm{Hf} /{ }^{177} \mathrm{Hf}=0.282482 \pm 0.000013\right.$; Sláma et al. 2008), which yielded ${ }^{176} \mathrm{Hf} /{ }^{177} \mathrm{Hf}$ mean ratios of $0.282654 \pm 0.000014(\mathrm{n}=1), 0.281673 \pm 0.000017(\mathrm{n}=8)$, $0.282519 \pm 0.000015(\mathrm{n}=9), 0.282006 \pm 0.000019(\mathrm{n}=7)$ and $0.282485 \pm 0.000014(\mathrm{n}=9)$, respectively $( \pm 2 S D)$; all values within the uncertainties and in good agreement with the accepted standard ratios.

For the calculation of the $\varepsilon H f$ values, the chondritic values reported by Bouvier et al. (2008) of ${ }^{176} \mathrm{Hf} /{ }^{177} \mathrm{Hf}=0.282785$ \pm 11 and ${ }^{176} \mathrm{Lu} /{ }^{177} \mathrm{Hf}=0.0336 \pm 1$ were used. To calculate the model ages $\left(\mathrm{T}_{\mathrm{DM}}\right)$ based on a depleted mantled source, the present-day ratios of ${ }^{176} \mathrm{Hf} /{ }^{177} \mathrm{Hf}=0.28325$ and ${ }^{176} \mathrm{Lu} /{ }^{177} \mathrm{Hf}=0.0388$ were used (Griffin et al. 2000, updated by Andersen et al. 2009). $\varepsilon \mathrm{Hf}(\mathrm{t})$ values were calculated using ${ }^{206} \mathrm{~Pb} /{ }^{238} \mathrm{U}$ ages of each analysed spot. The $\lambda$ decay constant for ${ }^{176} \mathrm{Lu}$ used is $1.867 \times 10^{-11} / \mathrm{yr}$ (Söderlund et al. 2004).

\section{RESULTS}

\section{Sample FRP327G}

This sample is from a meter-thick augen-gneiss sill of the Afeição Suite interleaved within garnet-mica schist mapped as part of the Santa Filomena Complex at Carnaíba creek, at the Acauã-Monte Orebe road (Figs. 2 and 3). Both schist and sill were later folded and deformed, presumably during the Brasiliano Orogeny. The close proximity to the main Afeição augen-gneiss pluton (near Afeição farm) suggests that this sill represents an apophysis projected from the batholith (Fig. 2). Recovered zircon crystals are euhedral bipyramidal $<250 \mu \mathrm{m}$ long prisms and needles with up to 5:1 aspect ratio, conspicuous internal zoning (Fig. 4) and high $\mathrm{Th} / \mathrm{U}$ ratios $(0.22-0.84)$, typical of igneous crystals (Tab. 1). Zircon crystals are mostly clear (translucid) with brownish colours and localized inclusions. Some of the crystals display a discrete few $\mu \mathrm{m}$-thick low-U (<45 ppm) bright border in CL images (Fig. 4). Eighteen spots were analysed in sixteen different crystals. Sixteen spots yielded a Discordia with an upper intercept at $953 \pm 30 \mathrm{Ma}$ and a high uncertainty close-to-zero lower intercept, all of the spots in high-U cores but one (14.1, in a low-U border). The six most concordant crystals yielded a Concordia age of $974 \pm 11 \mathrm{Ma}(2 \sigma ; \mathrm{MSWD}=0.59$; Fig. 5$)$. The slightly discordant points are interpreted as due to recent $\mathrm{Pb}$-loss, as hinted by the close-to-zero lower intercept of the Discordia. Thus, the Concordia age of $974 \pm 11 \mathrm{Ma}$ is interpreted as the best estimate for crystallization age of the magmatic protolith. The other two high-uncertainty spots (large ellipsis in Fig. 5A) are from bright low-U borders. Those are generally too thin for microprobe spot placement and yielded highly discordant data with ${ }^{207} \mathrm{~Pb} /{ }^{206} \mathrm{~Pb}$ ages between 547 and $1000 \mathrm{Ma}$ (Tab. 1), hinting they might be metamorphic rims with variable $\mathrm{Pb}$-loss related to the Brasiliano Orogeny.

Five of the most concordant zircon crystals were selected for Hf isotope analysis (Tab. 2). Those yielded homogeneous

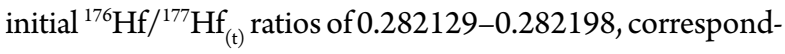
ing to moderately juvenile to slightly evolved $\varepsilon \mathrm{Hf}_{(\mathrm{t})}$ of -1.40 to +0.61 (Fig. 6) and with $\mathrm{T}_{\text {DMHf }}$ of $1.4-1.6 \mathrm{Ga}$.

\section{Sample FRP122}

This sample is from a metric granite sill concordantly interleaved within pelitic metarhythmite of the Morro Branco Complex in the Maravilha creek, near Capitão Gervásio Oliveira, Piauí (Fig. 2). Zircon crystals are stubby (2:1 aspect ratio), euhedral-subhedral bipyramidal prisms $<250 \mu \mathrm{m}$ long, mostly clear and transparent, but some showing minor inclusions. In CL images, the crystals show typical patterns of igneous internal zoning (Fig. 4) and $\mathrm{Th} / \mathrm{U}$ ratios, between 0.3 and 0.6 , are typical of primary (igneous) zircon crystals. This sample was dated by LA-ICPMS and the results were presented
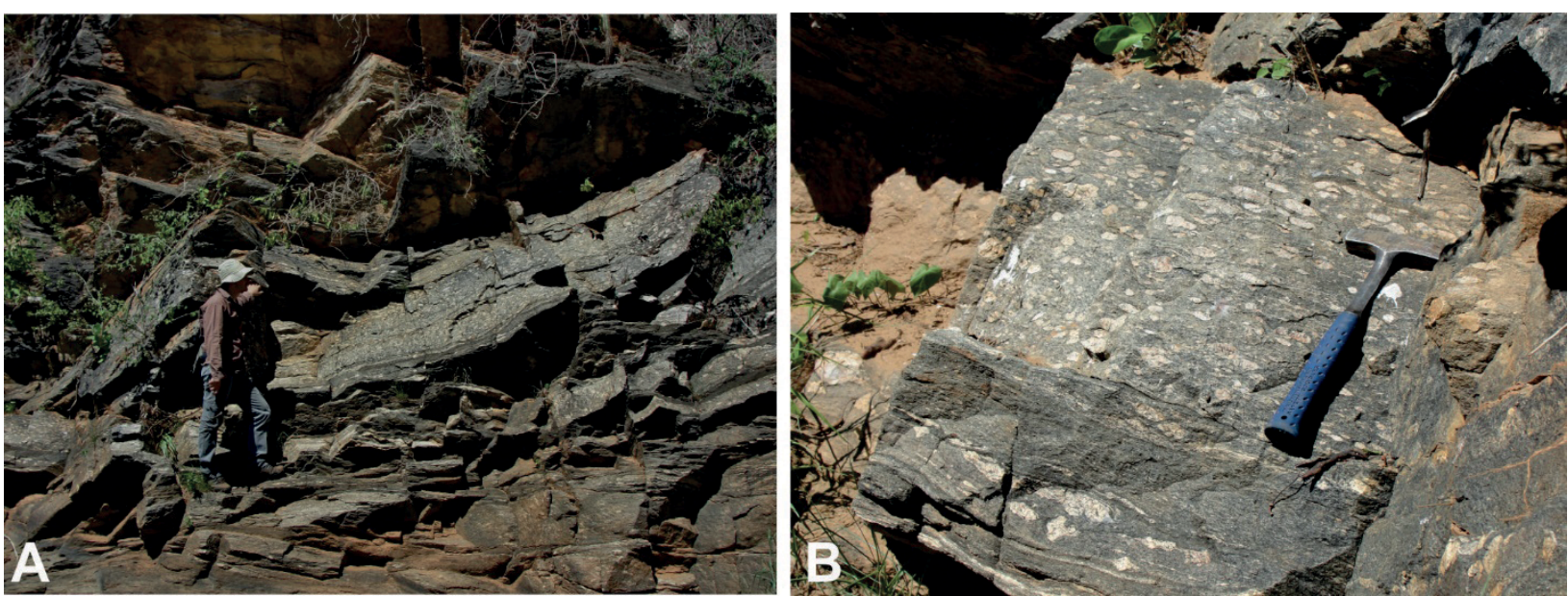

Figure 3. Metric augen-gneiss sill of the Afeição Suite intruding mica-schist mapped as part of the Santa Filomena Complex at station FRP327, Carnaíba Creek (Lat 8¹3'53”S / Long 4053'01”W). In (B), detail of (A). 
by Caxito et al. (2014b). The U-Pb isotope ratios of the analyzed zircon crystals cluster in a single coherent population in the Concordia diagram, and the eight most concordant zircon crystals yield a Concordia age of $1001.8 \pm 4.5 \mathrm{Ma}(2 \sigma$; MSWD = 1.2), which is interpreted to be the magmatic age of the granite, and also the minimum age of sedimentation of the metarhythmites within which it is interleaved.

Three of the most concordant zircon crystals were selected for Hf isotope analysis (Tab. 2). Those yielded homogeneous initial ${ }^{176} \mathrm{Hf} /{ }^{177} \mathrm{Hf}\left({ }_{(t)}\right.$ ratios of 0.282214-0.282219, corresponding to moderately juvenile $\varepsilon \mathrm{Hf}(\mathrm{t})$ of +2.20 to +2.41 (Fig. 6) and with $\mathrm{T}_{\mathrm{DMHf}}$ of $1.4 \mathrm{Ga}$.

\section{Sample FRP200}

This sample is from an augen-gneiss to the northwest of Paulistana, Piauí, between this town and São Francisco de Assis (Fig. 2). It is a NW-SE elongated body thrust upon the metavolcanosedimentary rocks of the Paulistana Complex. While in the central portion of the pluton it might be only slightly deformed, in its borders it is strongly foliated. Especially toward the north, the elongated body suffers a bending toward $\mathrm{NE}$, which is related to the late-Brasiliano dextral shearing of the western branch of the Pernambuco shear zone; this is represented in the field by the progressive mylonitization of the augen-gneiss, developing an E-W trending anastomosing

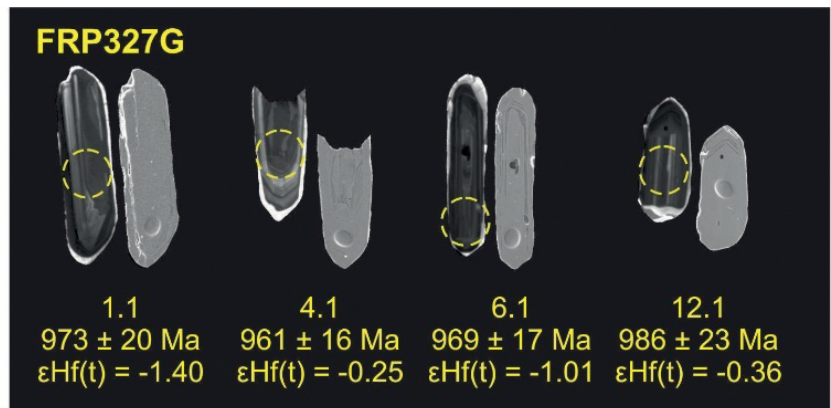

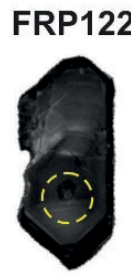

z11

$1000 \pm 6 \mathrm{Ma}$ $\varepsilon H f(t)=+2.38$

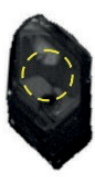

z3

$1010 \pm 7 \mathrm{Ma}$ $\varepsilon \mathrm{Hf}(\mathrm{t})=+2.41$

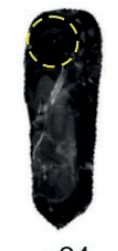

$$
\text { z24 }
$$

$999 \pm 6 \mathrm{Ma}$ $\varepsilon H f(t)=+2.20$

\section{FRP200}

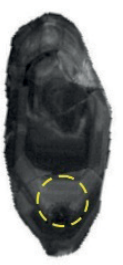

z23

$959 \pm 5 \mathrm{Ma}$

$\varepsilon \mathrm{Hf}(\mathrm{t})=-0.17$

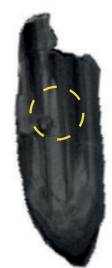

z27 $971 \pm 5 \mathrm{Ma}$ $\varepsilon \mathrm{Hf}(\mathrm{t})=-0.46$

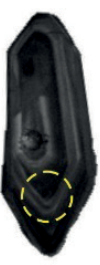

z9 $964 \pm 6 \mathrm{Ma}$ $\varepsilon \mathrm{Hf}(\mathrm{t})=-1.51$

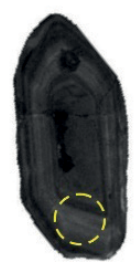

z6

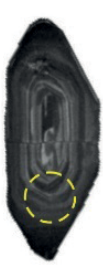

z16

$971 \pm 6 \mathrm{Ma}$

$\varepsilon H f(t)=-1.16$

$\varepsilon \mathrm{Hf}(\mathrm{t})=-0.47$
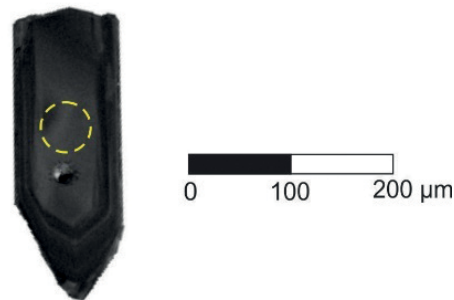

z11

$983 \pm 7 \mathrm{Ma}$

$\varepsilon \mathrm{Hf}(\mathrm{t})=-0.80$

Figure 4. $\mathrm{CL}$ and SE (FRP327G) images of selected zircon crystals from the studied samples. The doted circle represents spot placement for $\mathrm{Hf}$ analysis $(50 \mu \mathrm{m}$ diameter). Previous SHRIMP spots $(20 \mu \mathrm{m}$ diameter $)$ are visible on SE images of zircon crystals from sample FRP327G, and laser ablation spots $(20 \mu \mathrm{m}$ diameter) for $\mathrm{U}-\mathrm{Pb}$ analysis are visible on CL images of samples FRP122 and FRP200. Quoted ages are ${ }^{206} \mathrm{~Pb} /{ }^{238} \mathrm{U}$ dates.

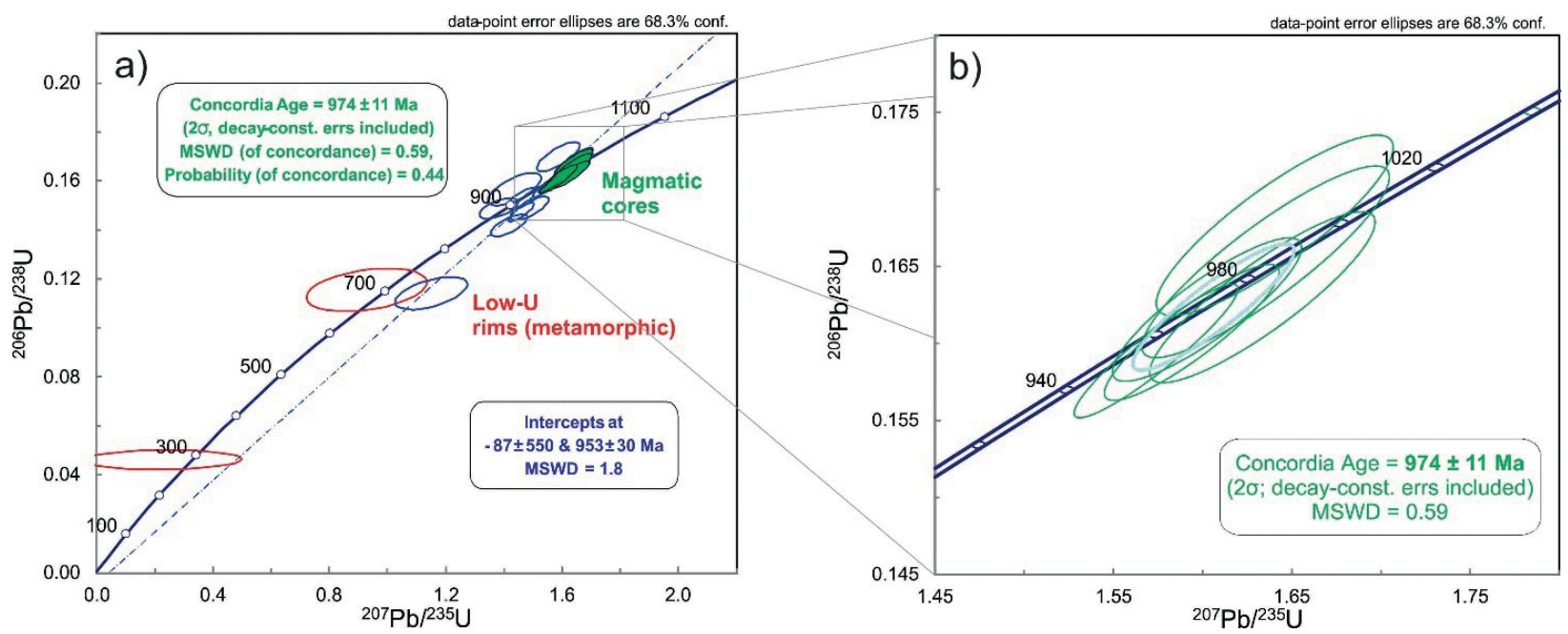

Figure 5. Concordia diagrams for sample FRP327G. The diagram in (B) represents a zoom into the grey square area in (A). Spots are colorcoded to represent the analysis used in calculation of the Discordia (upper intercept) age (blue), of the Concordia age (green) and low-U high-uncertainty rims not used for age calculation (red). 
foliation which involves the dextral-sense rotated feldspar porphyroclasts of the augen-gneiss.

Sample FRP200 is from the central and most undeformed portion of the pluton. Zircon crystals are clear, inclusion-free needle-like elongated euhedral prisms (up to 5:1 aspect ratio), with conspicuous concentric internal zoning (Fig. 4). The zircon crystals show typically igneous $\mathrm{Th} / \mathrm{U}$ ratios, between 0.1 and 0.4 . Those were dated by Caxito et al. (2014b) by LA-ICPMS, yielding a Concordia age of $966 \pm 4.6 \mathrm{Ma}(2 \sigma$, MSWD $=2.3$ ), which is interpreted to be the magmatic age of the granitic protolith.

Six spots in the most concordant zircon crystals were selected for $\mathrm{Hf}$ isotope analysis (Tab. 2). Those yielded ini-

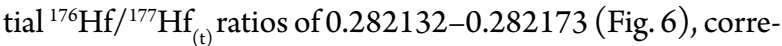
sponding to slightly evolved $\varepsilon \mathrm{Hf}_{(\mathrm{t})}$ of -1.51 to -0.17 and with $\mathrm{T}_{\mathrm{DMHf}}$ of $1.5 \mathrm{Ga}$.

\section{DISCUSSION}

The new $\mathrm{U}-\mathrm{Pb}$ data adds to the amassed dataset that shows the presence of ca. 1000-960 Ma rocks related to the Cariris Velhos event within the internal zone of the Riacho do Pontal Orogen (Caxito et al.2014b and references therein). The augengneiss sill dated at $974 \mathrm{Ma}$ intrudes metasedimentary rocks, and thus at least part of what is currently mapped as Santa Filomena Complex must be older than that, and probably related to the Cariris Velhos event. The fact that, in other parts of the internal zone of the Riacho do Pontal Orogen, samples of metasedimentary rocks also mapped as Santa Filomena Complex yield detrital zircon grains as young as ca. $650 \mathrm{Ma}$ (Brito Neves et al. 2015, Santos et al. 2017) highlights the difficulty of separating metasedimentary successions of distinct age and tectonic setting which were subjected to strong deformation and metamorphism during the Brasiliano Orogeny in this area. Probably, what is today mapped as Santa Filomena

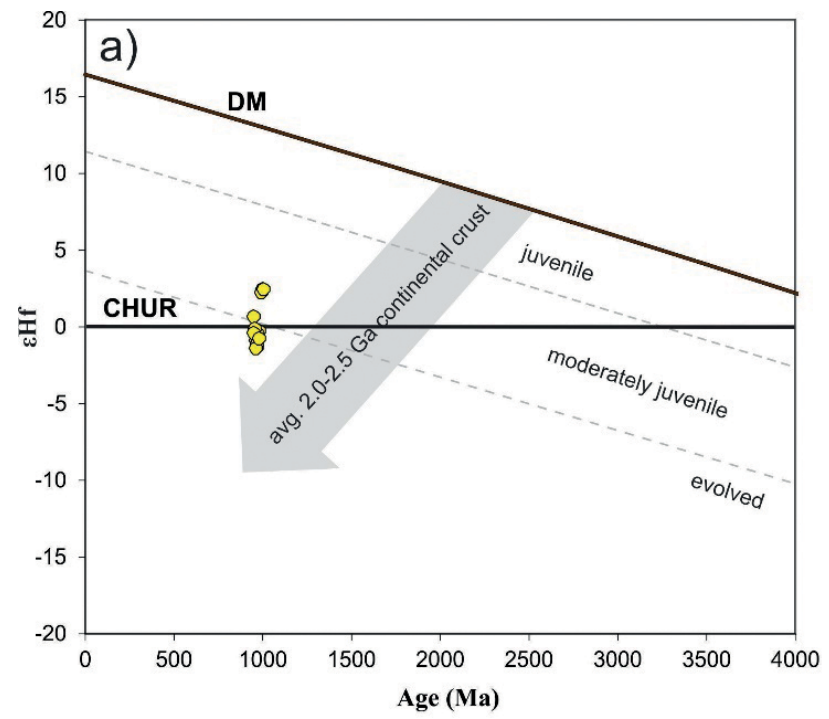

Complex encompasses both sedimentary basins related to the Tonian Cariris Velhos and the Ediacaran Brasiliano syn-orogenic sedimentation.

Moderately juvenile to slightly evolved near-chondritic Hf isotope data presented here for the first time (Tab. 2 and Fig. 6) suggest that the Afeição augen-gneisses represent neither juvenile (e.g., island-arc) rocks nor purely the remelting of ancient crustal rocks (Archean and Paleoproterozoic basement of the Transversal Zone). Instead, a scenario with the mixing of Tonian juvenile melts coming from a mantle wedge above a subduction zone with variable amounts of Archean and Paleoproterozoic basement is proposed to explain the $\mathrm{Hf}$ isotope characteristics of the Cariris Velhos augen-gneisses, generating intermediary Mesoproterozoic model ages (1.6 $1.2 \mathrm{Ga}$ ) which are the result of the two end-member mixing process. A similar interpretation was presented for $\mathrm{Nd}$ isotope data available for Cariris Velhos-related rocks, which also yield Mesoproterozoic $\mathrm{T}_{\mathrm{DM}}$ and positive to slightly negative $\varepsilon \mathrm{Nd}(\mathrm{t})$ (Kozuch 2003, Santos et al. 2010, Caxito et al. 2014b). Such scenario is coherent with a continental arc setting, as also suggested by the trace element patterns of Cariris Velhos gneisses (Kozuch 2003, Santos et al. 2010, Caxito et al. 2014b), which resemble Cordilleran granites. There is also an apparent slight tendency of the data to yield more juvenile $\varepsilon \mathrm{Hf}(\mathrm{t})$ for the oldest intrusions (ca. 1000), while the youngest (ca. 960) would yield more evolved data (Fig. 6). This trend, however, will only become clarified after more data is gathered and added to our pioneer dataset.

An alternative geotectonic model for the Cariris Velhos augen-gneisses was proposed by Neves (2003) and Guimarães et al. $(2012,2016)$, where those rocks would have been emplaced in an extensional, continental rift-related setting. It is interesting to notice that, interpreting similar lithogeochemical datasets, Neves (2003) and Guimarães et al. $(2012,2016)$ propose a distinct model and tectonic setting than Kozuch (2003), Santos

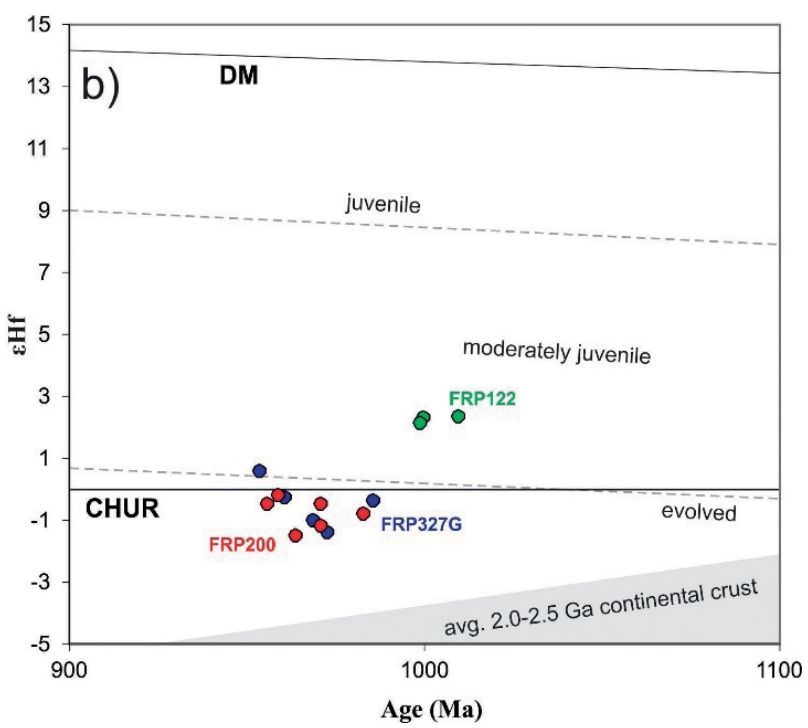

DM: Depleted Mantle; CHUR: Chondritic Uniform Reservoir.

Figure 6. Hf isotope evolution diagram for zircon samples of the Afeição Suite. The diagram in (B) represents a zoom in the area where the samples plot in the diagram in (A). Grey dashed lines classify fields of juvenile ( $0-5 \varepsilon$-units below DM), moderately juvenile ( $5-12 \varepsilon$-units below DM) and evolved (> $12 \varepsilon$-units below DM; Bahlburg et al. 2011). The grey band represents the average evolution of typical continental crust generated around $2.0-2.5 \mathrm{Ga}$, with a ${ }^{176} \mathrm{Lu} /{ }^{177} \mathrm{Hf}=0.010$ for felsic and ${ }^{176} \mathrm{Lu} /{ }^{177} \mathrm{Hf}=0.022$ for mafic crust (Pietranik et al. 2008). Model DM with present day ${ }^{176} \mathrm{Hf} /{ }^{177} \mathrm{Hf}$ ratio of 0.28325 and ${ }^{176} \mathrm{Lu} /{ }^{177} \mathrm{Hf}$ ratio of 0.0388 (Griffin et al. 2000, updated by Andersen et al. 2009). 
et al. (2010) and Caxito et al. (2014b). This highlights the difficulty of using lithogeochemical data to infer the tectonic settings of ancient metaigneous rocks. For instance, Caxito et al. (2014b) use diagrams that rely upon trace element data for the Afeição Suite augen-gneisses, which are generally thought to remain relatively immobile during post-crystallization processes, such as Th, Ta, Yb, Hf, $\mathrm{Nb}$ and $\mathrm{Zr}$ (Harris et al. 1986, Thiéblemont and Tegyey 1994, Gorton and Schandl 2000). In all of those diagrams, samples of the Afeição Suite augengneisses plot majoritarily in the Active Continental Margin, Volcanic Arc, or Collisional Calc-Alkaline/Syn-collisional fields, generally away from within-plate or anorogenic settings. Guimarães et al. (2016), on the other hand, uses the classic diagram of Eby (1992) for the discrimination of anorogenic granites where samples of the Afeição Suite, along with other Cariris Velhos samples, plot in the A2-type field.

As discussed by Guimarães et al. (2016), the majority of Tonian orthogneisses of the Borborema Province plot in the ferroan field in Frost et al. (2001) $\mathrm{SiO}_{2} \mathrm{x}(\mathrm{FeO} / \mathrm{FeO}+\mathrm{MgO})$ diagram, specifically in the upper right part $\left(\mathrm{SiO}_{2}>70 \%\right)$ of the diagram. A scatter to the magnesian field is, however, evident, especially when using the $\mathrm{SiO}_{2} \mathrm{x}(\mathrm{FeOtot} / \mathrm{FeOtot}+$ $\mathrm{MgO}$ ) diagram, recommended by Frost et al. (2001) on the basis that most modern chemical analysis do not distinguish between ferric and ferrous iron. Although ferroan magmas are typical of intraplate environments, Frost et al. (2001) noticed that they are not exclusive of those tectonic settings. In fact, about $17 \%$ of the Cordilleran-type granitoids in the dataset ( $\mathrm{n}=538$ ) of Frost et al. (2001) plot within the ferroan field. Excursions across the line that divide both fields are especially evident (although not exclusive) when $\mathrm{SiO}_{2}$ $>70 \%$, as its exactly the case for both the Afeição Suite and other granitoids related to the Cariris Velhos event (see Fig. 5D of Caxito et al. 2014b and Fig. 5B of Guimarães et al. 2012). For comparison, $96 \%$ of the A-type granitoids of the dataset $(\mathrm{n}=486)$ of Frost et al. (2001) plot in the ferroan field, without significant scatter to any part of the magnesian field. Thus, although classifications based on the contents of $\mathrm{FeO}$ and $\mathrm{MgO}$ are normally useful, as it has long been recognized that there are fundamental differences between rock suites that undergo iron enrichment during differentiation and those that do not show significant $\mathrm{FeO}$ enrichment relatively to $\mathrm{MgO}$ while $\mathrm{SiO}_{2}$ becomes enriched (Frost et al. 2001), samples of the Cariris Velhos augen-gneisses (and of the Afeição Suite) usually plot in the most ambiguous part of the proposed diagrams, and the scatter to the magnesian field hinders direct interpretation of the samples as typical ferroan A-type granites.

Plotting of Cariris Velhos samples in other diagrams that would allow separation between A-type and other types of granites are also ambiguous. For example, in the (FeO/ $\mathrm{MgO})$ versus $(\mathrm{Zr}+\mathrm{Nb}+\mathrm{Ce}+\mathrm{Y})$ tectonic discriminant diagram of Whalen et al. (1987), most samples plot in the borderline between the A-type granites field and the other fields (Fig. 10A of Guimarães et al. 2016), straddling the fractionated granites field and even the field of unfractionated M, Iand S-type granites.
Kozuch (2003), Santos et al. (2010) and Caxito et al. (2014b) interpret the fingerprints of subduction zones in normalized trace-element spidergram distributions of the Cariris Velhos orthogneisses. Kozuch (2003) and Santos et al. (2010) compiled data from different sources and proposed fields for typical extensional and convergent rock compositions, arguing that the Cariris Velhos orthogneisses plot within the convergent field, characterized by low $\mathrm{Nb}-\mathrm{Ta}, \mathrm{Sm}-\mathrm{Hf}$, and $\mathrm{Tb}-\mathrm{Yb}$ segments, and away from typical extensional patterns. Those are, however, although characteristic, not exclusive of arc-related granitoids, as exemplified by the interpretation of Guimarães et al. (2016) of the same normalized trace-element spidergrams as typical of A-type granites.

There is a possibility that rocks originated and emplaced in distinct tectonic settings might have been considered and treated as similar, based only on the crystallization age range. This is not unlikely when dealing with rocks scattered in such a wide area and especially when comparing such distant regions as the Rio Preto, Riacho do Pontal and Sergipano Belts of the Southern Borborema Province, with occurrences in the Transversal Zone and PEAL block. Treatment of rock samples emplaced and evolved in distinct settings would lead to significant scatter in the diagrams discussed above, blurring the original relations and difficulting interpretation. Thus, both temporal and spatial distinction should be made.

Temporally, we disagree that all of the Tonian rocks within the Borborema Province should be treated and interpreted together (i.e., as related to the Cariris Velhos event). For instance, in the Riacho do Pontal Belt, continental extension related to emplacement of a mantle plume and completely unrelated to the Cariris Velhos event was already underway at ca. $900 \mathrm{Ma}$ (Salgado et al. 2016), leading to the development of the Paulistana rift basin at ca. $888 \mathrm{Ma}$ and of new oceanic crust at ca. $820 \mathrm{Ma}$ (Caxito et al. 2016). Those rocks are all related to the rift and drift stages which would evolve to a complete Wilson Cycle during the Neoproterozoic culminating in the Brasiliano Orogeny (Caxito et al. 2016). They are, thus, not related to the Cariris Velhos event, which should be understood in the Riacho do Pontal area as occurring between 1000 and $960 \mathrm{Ma}$; and perhaps as young as ca. $920 \mathrm{Ma}$ in the remainder of the Transversal Zone (Santos et al. 2010). We disagree, then, with inclusion of rocks as young as ca. $870 \mathrm{Ma}$ as Cariris Velhos-related (Guimarães et al. 2016). In effect, A-type orthogneisses dated at ca. $869 \mathrm{Ma}$ in the eastern Transversal Zone (Neves et al. 2015) seem to be part of a middle Tonian rifting event similar to that discussed for the Riacho do Pontal area. In addition, based on the trace-element and isotope characteristics of the São Caetano supracrustal sequence of the Alto Pajeú Domain, Santos et al. (2019) described an extensional setting interpreted as a post-Cariris event at ca. $858 \mathrm{Ma}$. To our understanding, rocks related to the Cariris Velhos event are roughly bracketed between 1000 and $920 \mathrm{Ma}$, with middle Tonian rocks younger than that (ca. $900-820 \mathrm{Ma}$ ) being part of the rifting events in the Borborema Province related to Wilson cycles which would lead to the Brasiliano Orogeny.

Spatially, there is the possibility of distinct tectonic settings, coupled or not, being developed diachronolously over 
long distances. For instance, Kozuch (2003) and Santos et al. (2010) have made an interesting distinction of Tonian rocks emplaced in the Alto Pajeú domain (in a convergent arc setting) from those emplaced in the Riacho Gravatá subdomain (probably in an extensional, fore-arc or back-arc setting). Guimarães et al. (2016) consider the Serra da Pintada Suite of the Rio Preto Belt, in the extreme southwest of the Borborema Province, dated at $969 \pm 11 \mathrm{Ma}$ (Aquino and Batista 2011), as similar to the other Cariris Velhos occurrences in the Borborema Province. However, this is an alkaline suite composed of alkali-granites and syenites, with distinct normalized trace-element spidergrams (e.g., with no $\mathrm{Nb}$-Ta through), clearly plotting in the A-type field and in the within-plate granite fields of discrimination diagrams (Aquino and Batista 2011). Caxito et al. (2014a) and Alcântara et al. (2017) interpret the Serra da Pintada Suite as emplaced in an extensional setting related to the opening of a rift system which would be filled by the Canabravinha Formation sediments in the Rio Preto area. This setting is totally distinct from that occurring further northeast in both the Transversal Zone and in the Riacho do Pontal, Sergipano and PEAL areas, as also indicated by the distinct lithogeochemical signatures.

Another issue that deserves attention in future works is the petrogenesis and tectonic setting of mafic and ultramafic rocks which might be related to the Cariris Velhos event, including some retro-eclogitic remnants. For instance, Lages and Dantas (2016) studied the Floresta (Serrote das Pedras Pretas; Santos 1995) and Bodocó mafic-ultramafic units, which, according to the authors, constitute proto to marginal arc-back-arc basin systems that evolved between 1025 and $975 \mathrm{Ma}$, with arc cumulate rocks having evolved originally as picrite melts in suprasubduction ophiolite zones. Although the rocks related to the Cariris Velhos event are far from well understood, there is a larger dataset available for the felsic to intermediate augengneisses and metavolcanics than for the mafic and ultramafic rocks, and a clear picture of the belt's evolution will only be achieved by the study of the whole set of rocks.

As discussed by Neves (2003) and Guimarães et al. (2016), the lack of a well-defined metamorphic event related to the Cariris Velhos cycle is the main problem when trying to define an orogenic event of this age within the Borborema Province. However, accretionary processes and arc-continent collisions don't always produce significant deformation and metamorphism in the arc region. "Soft" collisions, where the arc region remains relatively undeformed, are not uncommon in the geologic record (Van Staal et al. 2011). Unfortunately, the low-U metamorphic rims in zircon crystals studied in this work are too thin and yielded results with too high uncertainties to be decisive in this case (Tab. 1 and Fig. 5). It is possible, as discussed by Medeiros (2004) and Caxito et al. (2014b), that metamorphism and structures related to the Cariris Velhos event (if this event is interpreted as a "hard" accretionary orogeny) have been largely obliterated by the late Neoproterozoic pervasive Brasiliano metamorphism and deformation. The definition of the existence and extent of the metamorphic event is a clear target for future research, and detailed petrographic and isotopic study of metamorphic rims and minerals should be conducted in order to clarify those issues. For instance, the 1.0 Ga metamafic-ultramafic rocks of the Serrote das Pedras Pretas Suite of the Alto Pajeu Domain are interpreted as a candidate of the oceanic remnants (Santos 1995) or arc-backarc sequences (Lages and Dantas 2016) related to the Cariris Velhos event. Lages and Dantas (2016) interpreted a low $\mathrm{Th} / \mathrm{U}(<0.1)$ zircon crystal of this suite with a ${ }^{206} \mathrm{~Pb} /{ }^{238} \mathrm{U}$ age of $967 \pm 9 \mathrm{Ma}$ as possible evidence of concomitant metamorphic processes during the Tonian (Lages and Dantas 2016). Further detailed geochronological work is necessary to confirm or dismiss a metamorphic event of this age.

Finally, recently acquired and processed magnetotelluric data suggest north-dipping crustal conductors as the dominant features in the Transversal Zone (Padilha et al. 2016). Considering the geometry and distribution of the conductors, Padilha et al. (2016) suggest that they represent remnants of an ancient subduction zone with enhanced conductivity associated with biogenic graphitized material originally deposited in a restricted oceanic environment. As the subsurface features correspond to the outcropping sites of Cariris Velhos-related rocks, including early Tonian rocks of oceanic affinity, Padilha et al. (2016) suggest that those are the relicts of an early Tonian subduction zone related to the Cariris Velhos event. Thus, geophysical data supports, in a first approximation, the continental arc model proposed by Kozuch (2003), Medeiros (2004), Santos et al. (2010), and Caxito et al. (2014b).

Based on the evidence discussed above, it is clear that from lithogeochemical data alone the tectonic setting of the Tonian orthogneisses of the Borborema Province is far from unambiguous and completely understood. However, we consider a continental arc setting for the Afeição augen-gneiss Suite and for most of the Cariris Velhos occurrences in the Alto Pajeú domain as the scenario that best explains the dataset gathered thus far. For instance, trace element data, which are usually regarded as immobile, point to a convergent setting in most discrimination diagrams. "Inheritance" of convergent-type lithogeochemistry due to the partial melting of older, Paleoproterozoic crust of arc affinity is not feasible because $\mathrm{Hf}$ and $\mathrm{Nd}$ isotope signatures clearly indicate the mixing of variable amounts of juvenile mantle and older crust, with important mantle input in the Tonian. This mantle input would strongly modify and obliterate the Paleoproterozoic geochemical signatures of the crustal sources. However, we recognize that further field, petrographic, geochemical, and isotopic work is necessary to characterize and fully understand the extent and importance of the Cariris Velhos event in the geology of the Borborema Province and of West Gondwana in general. In this process, it will be important to clearly separate, in both time and space, the rocks related to distinct tectonic settings and playing different roles, diachronously, throughout the Borborema Province.

\section{Concluding remarks}

The new U-Pb and Hf isotope data of the Afeição Suite presented here for the first time adds to the growing dataset that will help characterize and understand the tectonic setting and role of the augen-gneisses and metavolcanosedimentary rocks related to the Cariris Velhos event within the Borborema 
Province and West Gondwana in general. Isotope data derived from both $\mathrm{Nd}$ and $\mathrm{Hf}$ datasets suggest the mixing of a Tonian juvenile mantle source with variable amounts of older, Archean and Paleoproterozoic basement of the Borborema Province.

Interpretation of the available lithogeochemical dataset for Tonian rocks of the Borborema Province is far from unambiguous. To help resolve this issue, some spatial and temporal distinctions should be made. Temporally, we suggest that only rocks in the 1000 - 920 Ma should be considered as possibly related to the Cariris Velhos event. Tonian rocks younger than that are clearly related to post-Cariris extensional events, which would evolve to continental breakup and drifting and ultimately to complete Wilson Cycles related to the Brasiliano Orogeny during the Neoproterozoic. Spatially, we stress that tectonic settings evolve diachronously in extensive regions and that extensional settings might develop coeval to adjacent compressional settings, coupled (e.g., in the back-arc region) or not.

Even after those distinctions are done, interpretation of lithogeochemistry data will probably still be far from definitive in characterizing the geotectonic setting of Cariris Velhosrelated rocks. To a first approximation, however, trace element data which are generally thought to be immobile (Th, Ta, Yb, $\mathrm{Hf}, \mathrm{Nb}, \mathrm{Zr}$ ) all point to a convergent, arc-related setting for most of the Cariris Velhos occurrences, including the Afeição Suite. Interpretations that the subduction-related geochemical fingerprints would have been "inherited" from the remelting of arc-related Paleoproterozoic rocks are ruled out by $\mathrm{Hf}$ and $\mathrm{Nd}$ isotope data, which clearly suggest the important input of juvenile mantle-derived melts that would largely obliterate the geochemical signatures of remelted crustal sources during the Tonian.

Arguably, the greatest challenge to the interpretation of a convergent-type setting for the Cariris Velhos Belt is the lack of a well-defined metamorphic event related to this orogenic pulse. This is a clear target for further detailed petrographic and isotopic work, in search of metamorphic rims and minerals which would help clarify this and other issues in the geology of the Borborema Province. The possibility of "soft" accretionary processes, with relatively low deformation and metamorphism in the arc region, must also be investigated.

In order to achieve a better understanding of the evolution of the Cariris Velhos event in the Borborema Province, as a final remark we would like to stress the importance of studying, besides the felsic to intermediate orthogneisses and related metavolcanic rocks, also the mafic and ultramafic components, which are not as detailed as the first. Recent studies suggest the presence of arc-back-arc and suprasubduction zone mafic-ultramafic associations, and this is clearly a subject for further research. Also, the integration of surface geology with subsurface geophysical information will be crucial for further assessing the importance of the Cariris Velhos event for the evolution of the Borborema Province. Magnetotelluric data, for instance, suggest the presence of north-dipping conductors interpreted as remnants of ancient subduction zones corresponding to the outcropping sites of early Tonian rocks related to the Cariris Velhos event in the Transversal Zone, lending further support to the continental arc model.

\section{ACKNOWLEDGMENTS}

This paper is an homage to the late Edilton Santos, whose lifetime of devotion to deciphering the geology of the Borborema Province is a standing incentive and role model to all of us. We would like to thank Brazilian funding agencies $\mathrm{CNPq}$, CAPES, and FAPEMIG among others for the sustained support to conduct scientific research in Brazil. FAC, AU, ELD, and CL are recipients of $\mathrm{CNPq}$ Research Productivity grants and acknowledge the support received. The U-Pb analyses were performed using a SHRIMP II probe at the John DeLaeter Centre of the Curtin University, Perth, Western Australia, enabled by NCRIS via AuScope. We thank Neal McNaughton for guidance and support during the preparation and analysis of the SHRIMP mounts and Allen Kennedy and Hao Gao for support during the analysis. A previous version was greatly enhanced after comments and suggestions by three anonymous reviewers.

\section{ARTICLE INFORMATION}

Manuscript ID: 20190082. Received on: 08/30/2019. Approved on: 01/27/2020.

FC designed the research, did fieldwork, sample collecting and preparation, U-Pb SHRIMP and Lu-Hf LA-ICP-MS analyses, wrote the first draft of the manuscript and prepared the original versions of the figures; LS aided in research design and improved the manuscript and figures through corrections and suggestions; AU participated in fieldwork and sample collecting, and aided in research design and manuscript revision; ED aided in the interpretation of the geochronological data and improved the manuscript through corrections and suggestions; AA and CL aided in Lu-Hf LA-ICP-MS data collection and reduction, spot placement and interpretation.

Competing interests: The authors declare no competing interests.

\section{REFERENCES}

Alcântara D.C.B.G., Uhlein A., Caxito F.A., Dussin I., Pedrosa-Soares A.C. 2017. Stratigraphy, tectonics and detrital zircon U-Pb (LA-ICP-MS) geochronology of the Rio Preto Belt and northern Paramirim corridor, NE, Brazil. Brazilian Journal of Geology, 47(2):261-273. http://dx.doi. org/10.1590/2317-4889201720160102

Almeida F.F.M., Hasui Y., Brito Neves B.B., Fuck R.A. 1981. Brazilian structural provinces: an introduction. Earth Science Reviews, 17(1-2):1-29. https://doi.org/10.1016/0012-8252(81)90003-9

Andersen T., Andersson U.B., Graham S., Åberg G., Simonsen S.L. 2009. Granitic magmatism by melting of juvenile continental crust: new constraints on the source of Palaeoproterozoic granitoids in Fennoscandia from Hf isotopes in zircon. Journal of the Geological Society, 166:233-247. https://doi.org/10.1144/0016-76492007-166
Aquino M.R., Batista I.H. 2011. Geologia e recursos minerais da folha Avelino Lopes SC.23-Z-A-III, escala 1:100.000. Programa Geologia do Brasil. Teresina, CPRM - Brazilian Geological Survey. 88 p.

Araújo C.E.G., Rubatto D., Hermann J., Cordani U.G., Caby R., Basei M.A.S. 2014. Ediacaran 2,500-km-long synchronous deep continental subduction in the West Gondwana Orogen. Nature Communications, 5:51-98. https:// doi.org/10.1038/ncomms6198

Araújo C.E.G., Cordani U.G., Agbossoumounde Y., Caby R., Basei M.A.S., Weinberg R.F., Sato K. 2016. Tightening-up NE Brazil and NW Africa connections: advances in zircon geochronology towards a complete plate tectonic cycle in the Dahomeyide belt of the West Gondwana Orogen in Togo and Benin. Precambrian Research, 276:29-42. https://doi. org/10.1016/j.precamres.2016.01.032 
Arthaud M.H., Caby R., Fuck R.A., Dantas E.L., Parente C.V. 2008. Geology of the northern Borborema Province, NE Brazil and its correlation with Nigeria, NW Africa. In: Pankhurst R.J., Trouw R.A.J., Brito Neves B.B., de Wit, M.J. (eds.), West Gondwana: Pre-Cenozoic Correlations Across the South Atlantic Region. Londres, Geological Society, Special Publications, 294, p. 49-67.

Bahlburg H., Vervoort J.D., DuFrane S.A., Carlotto V., Reimann C., Cárdenas J. 2011. The U-Pb and Hf isotope evidence of detrital zircons of the Ordovician Ollantaytambo Formation, southern Peru, and the Ordovician provenance and paleogeography of southern Peru and northern Bolivia. Journal of South American Earth Sciences, 32(3):196-209. https:// doi.org/10.1016/j.jsames.2011.07.002

Black L.P., Gulson B.L. 1978. The age of the Mud Tank Carbonatite, Strangways range, Northern Territory. BMR Journal of Australian Geology \& Geophysics, 3:227-232.

Black L.P., Kamo S.L., Allen C.M., Aleinikoff J.N., Davis D.W., Korsch R.J., Foudoulis C. 2003. TEMORA 1: a new zircon standard for Phanerozoic U-Pb geochronology. Chemical Geology, 200(1-2):155-170. https://doi. org/10.1016/S0009-2541(03)00165-7

Black L.P., Kamo S.L., Allen C.M., Davis D.W., Aleinikoff J.N., Valley J.W., Mundil R., Campbell I.H., Korsch R.J., Williams I.S., Foudoulis C. 2004. Improved $\mathrm{Pb}-206 / \mathrm{U}-218$ microprobe geochronology by the monitoring of a trace-element-related matrix effect; SHRIMP, ID-TIMS, ELA-ICPMS and oxygen isotope documentation for a series of zircon standards. Chemical Geology, 205(1-2):115-140. https://doi.org/10.1016/j. chemgeo.2004.01.003

Bouvier A., Vervoort J.D., Patchett P.J. 2008. The Lu-Hf and Sm-Nd isotopic composition of CHUR: constraints from unequilibrated chondrites and implications for the bulk composition of terrestrial planets. Earth and Planetary Science Letters, 273(1-2):48-57. https://doi.org/10.1016/j. eps1.2008.06.010

Brito Neves B.B. 1975. Regionalização Geotectônica do Pré-Cambriano Nordestino. Tese de Doutorado, Instituto de Geociências, Universidade de São Paulo, São Paulo, 198 p

Brito Neves B.B., Santos E.J., Van Schmus W.R. 2000. Tectonic history of the Borborema province. In: Cordani U.G., Milani E.J., Thomaz Filho A., Campos D.A. (eds.), Tectonic Evolution of South America. Rio de Janeiro, 31st International Geological Congress, p. 151-182.

Brito Neves B.B., Van Schmus W.R., Angelim L.A.A. 2015. Contribuição ao conhecimento da evolução geológica do Sistema Riacho do Pontal PE, BA, PI. Geologia USP, Série Científica, 15(1):57-93. http://dx.doi. org/10.11606/issn.2316-9095.v15ilp57-93

Brito Neves B.B., Van Schmus W.R., Fetter A.H. 2002. North-western Africa - North-eastern Brazil. Major tectonic links and correlation problems. Journal of African Earth Sciences, 34(3-4):275-278. https://doi. org/10.1016/S0899-5362(02)00025-8

Brito Neves, B.B., Van Schmus, W.R., Kozuch, M., Santos, E.J., Petronilho, L., 2005. A zona tectônica Teixeira Terra Nova-ZTTTN-fundamentos da geologia regional e isotópica. Geol. USP Sér. Cient. 5:57-80.

Brito Neves B.B., Van Schmus W.R., Santos E.J., Campos Neto M.C., Kozuch M. 1995. O evento Carirís Velhos na Província Borborema: integração de dados, implicações e perspectivas. Revista Brasileira de Geociências, 25(4):279-296

Caby R. 1989. Precambrian terranes of Benin, Nigeria and Northeast Brazil and the late Proterozoic South Atlantic fit. In: Dallmeyer R.D. (ed.), Terranes in the circum-Atlantic paleozoic orogens. Special Paper, Geology Society of America, 230, p. 145-158. https://doi.org/10.1130/ SPE230-p145

Carvalho M.J. 2005. Tectonic Evolution of the Marancó-Poço Redondo Domain: Records of the Cariris Velhos and Brasiliano Orogenesis in the Sergipano Belt, NE Brazil. Tese, Universidade de Campinas, Campinas, 202 p.

Caxito F.A. 2013. Geotectônica e evolução crustal das faixas Rio Preto e Riacho do Pontal, estados da Bahia, Pernambuco e Piauí. Tese, Universidade Federal de Minas Gerais, Belo Horizonte, 288 p.

Caxito F.A., Dantas E.L., Stevenson R., Uhlein A. 2014a. Detrital zircon $(\mathrm{U}-\mathrm{Pb})$ and $\mathrm{Sm}-\mathrm{Nd}$ isotope studies of the provenance and tectonic setting of basins related to collisional orogens: the case of the Rio Preto fold belt on the northwest São Francisco Craton margin, NE Brazil. Gondwana Research, 26(2):741-754. http://dx.doi.org/10.1016/j.gr.2013.07.007
Caxito F.A., Uhlein A., Dantas E.L. 2014b. The Afeição augen-gneiss Suite and the record of the Cariris Velhos Orogeny (1000-960 Ma) within the Riacho do Pontal fold belt, NE Brazil. Journal of South American Earth Sciences, 51:12-27. http://dx.doi.org/10.1016/j.jsames.2013.12.012

Caxito F.A., Uhlein A., Dantas E., Stevenson R., Egydio-Silva M., Salgado S.S. 2017. The Rio Preto and Riacho do Pontal Belts. In: Heilbron M. Cordani U., Alkmim F. (eds.), São Francisco Craton, Eastern Brazil. Regional Geology Reviews. Nova York, Springer, p. 221-239.

Caxito F.A., Uhlein A., Dantas E.L., Stevenson R., Salgado S.S., Dussin I.A., Sial A.N. 2016. A complete Wilson Cycle recorded within the Riacho do Pontal Orogen, NE Brazil: implications for the Neoproterozoic evolution of the Borborema Province at the heart of West Gondwana. Precambrian Research, 282:97-120. http://dx.doi.org/10.1016/j. precamres.2016.07.001

Caxito F.A., Uhlein A., Stevenson R., Uhlein G.J. 2014c. Neoproterozoic oceanic crust remnants in northeast Brazil. Geology, 42(5):387-390. http:// dx.doi.org/10.1130/G35479.1

Cruz R.F., Pimentel M.M., Accioly A.C.A., Rodrigues J.B. 2014. Geological and isotopic characteristics of granites from the Western PernambucoAlagoas Domain: implications for the crustal evolution of the Neoproterozoic Borborema Province. Brazilian Journal of Geology, 44(4):627-652. https:// doi.org/10.5327/Z23174889201400040008

Dada S.S. 2008. Proterozoic evolution of the Nigeria-Boborema province In: Pankhurst R.J., Trouw R.A.J., Brito Neves B.B., de Wit, M.J. (eds.), West Gondwana: Pre-Cenozoic Correlations Across the South Atlantic Region. Londres, Geological Society, Special Publications, 294, p. 122-136.

Eby G.N. 1992. Chemical subdivision of the A-type granitoids: petrogenetic and tectonic implications. Geology, 20(7):641-644. https://doi.org/10.1130/0091-7613(1992)020\%3C0641:CSOTAT\%3 E2.3.CO;2

Freitas M.S., Sachs L.L.B. 2012. Geologia e recursos minerais da Folha Riacho Queimadas, (SC.24-V-A-I) e 1:100.000. In: Congresso Brasileiro de Geologia, 46. Santos, SBG

Frost B.R., Barnes C.G., Collins W.J., Arculus R.J., Ellis D.J., Frost C.D 2001. A geochemical classification for granitic rocks. Journal of Petrology, 42(11):2033-2048.

Gorton M.P., Schandl E.S. 2000. From continents to island arcs: a geochemical index of tectonic setting for arc-related and within-plate felsic to intermediate volcanic rocks. Canadian Mineralogy, 38(5):1065-1073. https://doi.org/10.2113/gscanmin.38.5.1065

Griffin W.L., Pearson N.J., Belousova E., Jackson S.E., van Achterbergh E., O'Reilly S.Y., Shee S.R. 2000. The Hf isotope composition of cratonicmantle: LAM-MC-ICPMS analysis of zircon megacrysts in kimberlites. Geochimica et Cosmochimica Acta, 64(1):133-147. https://doi.org/10.1016/ S0016-7037(99)00343-9

Guimarães I.P., Brito M.F.L., Lages G.A., Silva Filho A.F., Santos L., Brasilino R.G. 2016. Tonian granitic magmatism of the Borborema Province, NE Brazil: A review. Journal of South American Earth Sciences, 68:97-112. https://doi.org/10.1016/j.jsames.2015.10.009

Guimarães I.P., Van Schmus W.R., Brito Neves B.B., Bittar S.M.B., Silva Filho A.F., Armstrong R. 2012. U-Pb zircon ages of orthogneisses and supracrustal rocks of the Cariris Velhos belt: Onset of Neoproterozoic rifting in the Borborema Province, NE Brazil. Precambrian Research, 192195:52-77. https://doi.org/10.1016/j.precamres.2011.10.008

Harris N.B.W., Pearce J.A., Tindle A.G. 1986. Geochemical characteristics of collision-zone magmatism. In: Coward M.P., Ries A.C. (eds.), Collision Tectonics. Londres, Geological Society Special Publication, v. 19, p. 67-81.

Hurley P.M., Rand J.R., Pinson W.H., Fairbarn H., Almeida F.F.M., Melcher G.C., Cordani U.G., Kawashita K., Vandoros P. 1967. Test of continental drift by means of radiometric ages. Science, 157(3788):495-500. https:// doi.org/10.1126/science.157.3788.495

Jackson, S. E., Pearson, N. J., Griffin, W. L., \& Belousova, E. A. (2004). The application of laser ablation-inductively coupled plasma-mass spectrometry to in situ U-Pb zircon geochronology. Chemical Geology, 211(1-2):47-69.

Jardim de Sá E.F., Macedo M.H.F., Fuck R.A., Kawashita K. 1992. Terrenos proterozóicos na província Borborema e a margem norte do Cráton do São Francisco. Revista Brasileira de Geociências, 22(4):472-480. 
Jardim de Sá E.F., Macedo M.H.F., Torres H.H.F., Kawashita K. 1988. Geochronology of metaplutonics and evolution of supracrustal belts in the Borborema Province, NE Brazil. In: Congresso Latino-Americano de Geologia, 7., Belém. Anais... p. 49-62.

Kozuch M. 2003. Isotopic and trace element geochemistry of early Neoproterozoic gneissic and metavolcanic rocks in the Cariris Velhos orogen of the Borborema Province, Brazil, and their bearing on tectonic setting. Tese, University of Kansas, Lawrence, 199 p.

Lages G.A., Dantas E.L. 2016. Floresta and Bodocó Mafic-Ultramafic Complexes, western Borborema Province, Brazil: Geochemical and isotope constraints for evolution of a Neoproterozoic arc environment and retroeclogitic hosted Ti-mineralization. Precambrian Research, 280:95-119. https://doi.org/10.1016/j.precamres.2016.04.017

Ludwig K.R. 2008. User's Manual for Isoplot 3.71. A Geochronological Toolkit for Excel. Special Publication Number 4. Berkeley, Berkeley Geochronological Center, $76 \mathrm{p}$.

Ludwig K.R. 2009. SQUID 2: A User's Manual. Berkeley, Berkeley Geochron. Ctr. Spec. Pub. 5, 110 p.

Medeiros V.C. 2004. Evolução geodinâmica e condicionamento estrutural dos terrenos Piancó-Alto Brígida e Alto Pajeú, Domínio da Zona Transversal, NE do Brasil. Tese, Universidade Federal do Rio Grande do Norte, Natal, 200 p.

Neves S.P. 2003. Proterozoic history of the Borborema province (NE Brazil): Correlations with neighboring cratons and Pan-African belts and implications for the evolution of western Gondwana. Tectonics, 22(4):1031. http://doi.org/10.1029/2001TC001352

Neves, S.P.; Bruguier, O.; Silva, J.M.R.; Mariano, G.; Silva Filho, A.F.; Teixeira, C.M.L., 2015. From extension to shortening: Dating the onset of the Brasiliano Orogeny in eastern Borborema Province (NE Brazil). Journal of South American Earth Sciences 58, 238-256

Oliveira, R.G., 1998. Arcabouço geotectônico da região da Faixa Riacho do Pontal, Nordeste do Brasil: dados aeromagnéticos e gravimétricos. Unpublished Masters Dissertation. IG-USP, São Paulo, Brazil, 157 p.

Oliveira E.P., Toteu S.F., Araújo M.N.C., Carvalho M.J., Nascimento R.S., Bueno J.F., McNaughton N., Basilici G. 2006. Geologic correlation between the Neoproterozoic Sergipano belt (NE Brazil) and the Yaoundé schist belt (Cameroon, Africa). Journal of African Earth Sciences, 44(4-5):470-478. https://doi.org/10.1016/j.jafrearsci.2005.11.014

Oliveira, E.P., Windley, B.F., Araújo, M.N.C. 2010. The Neoproterozoic Sergipano orogenic belt, NE Brazil: a complete plate tectonic cycle in western Gondwana. Precambrian Research, 181:64-84.

Oliveira R.G. 2008. Arcabouço geofísico, isostasia e causas do magmatismo cenozoico da Província Borborema e sua margem continental (nordeste do Brasil). Tese, Universidade Federal do Rio Grande do Norte, Natal, 411 p.

Oliveira R.G., Medeiros W.E. 2018. Deep crustal framework of the Borborema Province, NE Brazil, derived from gravity and magnetic data. Precambrian Research, 315:45-65. https://doi.org/10.1016/j. precamres.2018.07.004

Padilha A.L., Vitorello I., Pádua M.B., Fuck R.A. 2016. Deep magnetotelluric signatures of the early Neoproterozoic Cariris Velhos tectonic event within the Transversal sub-province of the Borborema Province, NE Brazil. Precambrian Research, 275:70-83. https://doi.org/10.1016/j. precamres.2015.12.012

Perpétuo M.P. 2017. Petrografia, geoquímica e geologia isotópica (U-Pb, Sm$\mathrm{Nd}$ e Sr-Sr) dos granitoides ediacaranos da porção norte do orógeno Riacho do Pontal. Dissertação, Universidade Estadual de Campinas, Campinas, 114 p.

Pietranik A.B., Hawkesworth C.J., Storey C.D., Kemp A.I.S., Sircombe K.N., Whitehouse M.J., Bleeker W. 2008. Episodic, mafic crust formation from 4.5 to $2.8 \mathrm{Ga}$ : new evidence from detrital zircons, Slave craton, Canada. Geology, 36(11):875-878. https://doi.org/10.1130/G24861A.1

Salgado S.S., Ferreira Filho C.F., Caxito F.A., Uhlein A., Dantas E.L., Stevenson R. 2016. The Ni-Cu-PGE mineralized Brejo Seco mafic-ultramafic layered intrusion, Riacho do Pontal Orogen: onset of Tonian (ca. $900 \mathrm{Ma}$ ) continental rifting in Northeast Brazil. Journal of South American Earth Sciences, 70:324-339. http://dx.doi.org/10.1016/j.jsames.2016.06.001

Santos E.J. 1995. O complexo granítico Lagoa das Pedras: acresção e colisão na região de Floresta (Pernambuco), Província Borborema. Tese, Instituto de Geociências da Universidade de São Paulo, São Paulo, 228 p.
Santos, E.J., Oliveira, R.G., Paiva, I.P., 1997. Terrenos no Domínio Transversal da Província Borborema: controles sobre acresção e retrabalhamento crustais ao sul do lineamento Patos. In: SBG-NE, XVII Simpósio de Geologia do Nordeste, Fortaleza, Brazil, pp. 141-144.

Santos E.J., Van Schmus W.R., Kozuch M., Brito Neves B.B. 2010. The Cariris Velhos tectonic event in northeast Brazil. Journal of South American Earth Sciences, 29(1):61-76. https://doi.org/10.1016/j.jsames.2009.07.003

Santos F.H., Amaral W.S., Luvizotto G.L., Martins de Sousa D.F. 2018. P-T evolution of metasedimentary rocks of the Santa Filomena Complex, Riacho do Pontal Orogen, Borborema Province (NE Brazil): Geothermobarometry and metamorphic modelling. Journal of South American Earth Sciences, 82:91-107.https://doi.org/10.1016/j.jsames.2017.12.013

Santos F.H., Amaral W.S., Uchôa Filho E., Martins D.T. 2017. Detrital zircon $\mathrm{U}-\mathrm{Pb}$ ages and whole-rock geochemistry of the Neoproterozoic Paulistana and Santa Filomena complexes, Borborema Province, northeastern Brazil: implications for source area composition, provenance, and tectonic setting. International Geology Review, 59(15):1861-1884. https://doi.org/ $10.1080 / 00206814.2017 .1300074$

Santos L.C.M.L., Dantas L., Cawood P., Lages G., Lima H., Santos E.J., Caxito F.A. 2019. Early to late Neoproterozoic subduction-accretion episodes in the Cariris Velhos Belt of the Borborema Province, Brazil: Insights from isotope and whole-rock geochemical data of supracrustal and granitic rocks. Journal of South American Earth Sciences, 96:102384. https:// doi.org/10.1016/j.jsames.2019.102384

Santos M.M., Lana C., Scholz R., Buick I., Schmitz M.D., Kamo S.L., Gerdes A., Corfu F., Tapster S., Lancaster P., Storey C.D., Basei M.A.S., Tohver E., Alkmim A., Nalini H., Krambrock K., Fantini C., Widenbeck M. 2017. A new appraisal of sri lankan bb zircon as a reference material for LA-ICP-MS U-Pb geochronology and Lu-Hf isotope tracing. Geostandards and Geoanalytical Research, 41(3):335-358. https://doi.org/10.1111/ggr.12167

Silva Filho A.F., Guimarães I.P., Van Schmus W.R. 2002. Crustal evolution of the Pernambuco-Alagoas complex, Borborema Province, NE Brazil; $\mathrm{Nd}$ isotopic data from neoproterozoic granitoids. Gondwana Research, 5(2):409-422. https://doi.org/10.1016/S1342-937X(05)70732-2

Silva Filho A.F., Guimarães I.P., Van Schmus W.R., Armstrong R.A., Rangel da Silva J.M., Osako L.S., Cocentino L. 2014. SHRIMP U-Pb zircon geochronology and $\mathrm{Nd}$ signatures of supracrustal sequences and orthogneisses constrain the Neoproterozoic evolution of the PernambucoAlagoas domain, southern part of Borborema Province, NE Brazil. International Journal of Earth Science, 103(8):2155-2190. https://doi. org/10.1007/s00531-014-1035-4

Sláma J., Košler J., Condon D.J., Crowley J.L., Gerdes A., Hanchar J.M., Horstwood M.S.A., Morris G.A., Nasdala L., Norberg N., Schaltegger U., Schoene B., Tubrett M.N., Whitehouse M.J. 2008. Plešovice zircon - a new natural reference material for $\mathrm{U}-\mathrm{Pb}$ and $\mathrm{Hf}$ isotopic microanalysis. Chemical Geology, 249(1-2):1-35. https://doi.org/10.1016/j.chemgeo.2007.11.005

Söderlund U., Patchett J.P., Vervoort J.D., Isachsen C.E. 2004. The ${ }^{176} \mathrm{Lu}$ decay constant determined by $\mathrm{Lu}-\mathrm{Hf}$ and $\mathrm{U}-\mathrm{Pb}$ isotope systematics of Precambrian mafic intrusions. Earth and Planetary Science Letters, 219(34):311-324. https://doi.org/10.1016/S0012-821X(04)00012-3

Stern R.S., Bodorkos S., Kamo S.L., Hickman A.H., Corfu F. 2009. Measurement of SIMS instrumental mass fractionation of $\mathrm{Pb}$-isotopes during zircon dating. Geostandards and Geoanalytical Research, 33(2):145168. https://doi.org/10.1111/j.1751-908X.2009.00023.x

Thiéblemont D., Tegyey M. 1994. Une discrimination géochimique des roches différenciées témoin de la diversité d'origine et de situation tectonique des magmas calco-alcalins. Comptes Rendus de l'Académie des Sciences, 319(1):87-94.

Trompette R.R. 1994. Geology of Western Gondwana (2000-500 Ma). PanAfrican-Brasiliano aggregation of South America and Africa. Rotterdam, Balkema, $350 \mathrm{p}$.

Trompette R.R. 1997. Neoproterozoic ( $600 \mathrm{Ma})$ aggregation of Western Gondwana: a tentative scenario. Precambrian Research, 82(1-2):101-112. https://doi.org/10.1016/S0301-9268(96)00045-9

Van Schmus W.R., Brito Neves B.B., Hackspacher P., Babinski M. 1995. $\mathrm{U} / \mathrm{Pb}$ and $\mathrm{Sm} / \mathrm{Nd}$ geochronolgic studies of eastern Borborema Province, northeastern Brazil: initial conclusions. Journal of South American Earth Sciences, 8(3-4):267-288. http://doi.org/10.1016/0895-9811(95)00013-6 
Van Schmus W.R., Kozuch M., Brito Neves B.B. 2011. Precambrian history of the Zona Transversal of the Borborema Province, NE Brazil: Insights from $\mathrm{Sm}-\mathrm{Nd}$ and $\mathrm{U}-\mathrm{Pb}$ geochronology. Journal of South American Earth Sciences, 31(2-3):227-252. https://doi.org/10.1016/j. jsames.2011.02.010

Van Schmus W.R., Oliveira E.P., Silva Filho A.F., Toteu F., Penaye J., Guimarães I.P. 2008. Proterozoic links between the Borborema Province, NE Brazil, and the Central African Fold Belt. In: Pankhurst R.J., Trouw R.A.J., Brito Neves B.B., de Wit M.J. (eds.), West Gondwana: Pre-Cenozoic correlations Across the South Atlantic Region. Londres, Geological Society Special Publications, 294, p. 69-99.

Van Staal C., Zagorevski A., Castonguay S., Massonne H., McNicoll V., Willner A.P. 2011. Variations in Tectonic Styles of Arc-Continent
Collisions. American Geophysical Union, Fall Meeting 2011, abstract id. T43H-04.

Whalen, J. B., Currie, K. L., \& Chappell, B. W. 1987. A-type granites: geochemical characteristics, discrimination and petrogenesis. Contributions to mineralogy and petrology, 95(4):407-419.

Woodhead J.D., Hergt J.M. 2005. A preliminary appraisal of seven natural zircon referencematerials for in situ Hf isotope determination. Geostandards and Geoanalytical Research, 29(2):183-195.https://doi.org/10.1111/j.1751-908X.2005.tb00891.x

Wu F.Y., Yang Y.H., Xie L.W., Yang J.H., Xu P., 2006. Hf isotopic compositions of the standard zircons and baddeleyites used in U-Pb geochronology. Chemical Geology, 234(1-2):105-126. https://doi.org/10.1016/j.chemgeo.2006.05.003 